\title{
Social vulnerability to floods in two coastal megacities: New York City and Mumbai
}

\author{
Alex de Sherbinin and Guillem Bardy*
}

\section{Abstract}

In this paper we assess differential exposure to flooding in two coastal megacities, New York and Mumbai, both of which suffered major flood-related disasters in the past decade. Specifically, we examine whether the most exposed populations are also the most socially vulnerable. First, we developed Social Vulnerability Indices (SoVIs) for each city with census data. We then overlaid the SoVI scores onto flood extent maps for Hurricane Sandy (New York, October 2012) and the Mumbai flash floods (July 2005), as well as for the evacuation zones for New York, to examine patterns of differential exposure. Our results suggest a degree of differential exposure in New York, especially in the highest flood risk areas, and provide fairly clear evidence for differential exposure in Mumbai. However, differences in the input resolution and confidence in the datasets for Mumbai make the results more uncertain. The paper concludes with a discussion of the policy implications and the data needs for urban spatial vulnerability assessments.

\section{Introduction}

There is growing interest among researchers and policy-makers in the risks to and the vulnerability of cities as the climate changes. This issue is attracting considerable attention in response to mounting evidence that the probability of extreme events of high magnitudes is increasing owing to anthropogenic climate change (Fischer \& Knutti 2015, IPCC 2012, IPCC 2007); that the world's population is becoming increasingly urban (UNFPA 2007); and that urban systems are particularly susceptible to certain kinds of climate impacts, such as storm surges, cyclones with high winds, floods, extreme heat, and-over the long term-sea

\footnotetext{
* Alex de Sherbinin (corresponding author), Center for International Earth Science Information Network (CIESIN), The Earth Institute, Columbia University, USA

Email: adesherbinin@ciesin.columbia.edu

Guillem Bardy, École Polytechnique, Paris, France
}

DOI: 10.1553/populationyearbook2015s131 
level rise (SLR) (Jha et al. 2012, Rosenzweig et al. 2011a). Although vulnerability assessment is gaining increasing attention, the literature on urban areas and climate change tends to be more heavily weighted toward impact and risk assessment, in which the focus is on the likely damage to infrastructure or health impacts on populations from events of various magnitudes (Lane et al. 2013, Rosenzweig et al. 2011a, Preston et al. 2007). A high proportion of these studies focus on flood and storm surge risk (UN HABITAT 2013, Jha et al. 2012, Storch et al. 2011, Kit et al. 2011, Rosenzweig et al. 2011b, Hallegate et al. 2010, Lin et al. 2010, Nicholls et al. 2008, Kleinen and Petschel-Held 2007), although populations who face risks related to heat waves (Wilhelmi et al. 2004, Kinney et al. 2000) and drought (and attendant water scarcity) (McDonald et al. 2011) are also included in some risk assessments.

Climate and risk researchers have often focused on infrastructure impact assessment using top-down expert- or model-driven approaches because they are less complex than approaches that incorporate social vulnerability (Soares et al. 2012, Cutter et al. 2003). Yet social vulnerability to climate change is also high, especially in urban areas with large, concentrated populations and a high degree of social stratification (Romero Lankao and Qin 2010). It is now widely appreciated that differences in demographic characteristics-e.g. income, educational level, race, social class, housing type, and occupation-are key contributors to social vulnerability (WHO 2010). Cutter et al. (2003) defined these characteristics as "social factors that influence or shape the susceptibility of various groups to harm and that also govern their ability to respond". ${ }^{1}$ Differential vulnerability based on factors such as race, ethnicity, income, and gender was identified by Soares et al. (2012) as one of nine key concepts in vulnerability research. According to Pelling (2002), "the matter of which groups of people are exposed to living with physical insecurity is not decided by random forces," but rather by patterns of political exclusion, wealth differentials, and power relations. Although there is evidence that urban populations with higher levels of social vulnerability generally suffer greater impacts from climate-related hazards (Reckien et al. forthcoming and 2013, Cutter and Emrich 2006, Laska 2006), there is less research that combines spatial patterns of social vulnerability and exposure to test the hypothesis, articulated by Pelling, that populations with higher levels of social vulnerability are more exposed to climate hazards than populations who are less socially vulnerable.

The goal of this paper is to use spatial methods to test the hypothesis that there are higher levels of social vulnerability in flood-prone areas of New York City and Mumbai. We use the term 'differential exposure' rather than the term 'differential vulnerability' (Soares et al. 2012), which focuses on population characteristics that make some population groups more sensitive to environmental stressors than others.

1 Throughout this paper, we use the term vulnerability in the sense of social, contextual, or intrinsic vulnerability (O'Brien et al. 2007); rather than in the sense of outcome vulnerability, defined by the IPCC fourth assessment report as comprising exposure, sensitivity, and adaptive capacity (Parry et al. 2007). 
There are theoretical reasons that would both support and refute a proposed link between high levels of social vulnerability and flood exposure. On the one hand, areas exposed to floods may have lower housing prices, which tend to attract poorer and less informed populations. There is evidence that this is the case in two highly flood-prone cities: Kampala, Uganda (Sliuzas et al. 2013, Nyakaana 2006) and Lagos, Nigeria (Agbola and Agunbiade 2009). On the other hand, wealthier people may be more exposed to coastal flooding, as property prices are often highest in close proximity to the shore. The collective action literature suggests, however, that wealthier populations are often able to mobilize to obtain the coastal infrastructure needed to protect their homes, and may therefore be less exposed than poorer populations (Adger 2003). Thus, on balance it is possible to argue that in all but the most extreme events the wealthiest populations are the least likely of the income groups to be exposed. We return to these theoretical linkages in our concluding discussion.

We chose to focus on New York City and Mumbai because they represent socioeconomically diverse cities at different ends of the global development spectrum that are highly vulnerable to flood hazards, and because they can be used to illustrate how the spatial resolution of data inputs affects our confidence in the results. First, we summarize recent research on spatial approaches to assessing differential exposure. We then discuss the two cities' levels of vulnerability to flood hazards, followed by a presentation of methods and results. We conclude with a discussion of broader issues related to uncertainty and the spatial resolution of input data in vulnerability assessments, and of the theoretical and policy implications of this research.

\section{Literature review}

While there is relatively abundant environmental justice (EJ) literature that shows that poor neighborhoods are differentially exposed to environmental hazards in the form of polluting industries, toxic waste sites, and air pollution sources such as highways (e.g. Crowder and Downey 2010, Mitchell and Dorling 2003, Bowen et al. 1995), there is less work that explores differential exposure to climate-related hazards (Reckien et al. forthcoming). An early study on differential exposure to climate hazards was conducted by Pelling (2002) in Santo Domingo, Dominican Republic. He employed survey methods to examine local patterns of self-organization and resilience in the aftermath of Hurricane Georges in 1998. However, he focused only on one community that was both low-income and exposed to natural hazards owing to its location on a river bank that experienced flooding during the hurricane. Thus, the research design could not answer the question of whether low-income communities in Santo Domingo were differentially exposed to flood hazards.

In the United States, Hurricane Katrina-which struck New Orleans, Louisiana, in August 2005-was a signature climate event that revealed differential vulnerability, though not necessarily differential exposure. Curtis et al. (2007) used 
census and public health data to explore the geography and characteristics of poverty in New Orleans prior to Hurricane Katrina, and how the specific locations and living situations of the residents contributed to outcomes. They found that the floods affected comparably well off and poorer communities almost equally, but that the impacts were greater in low-income communities because people living in these neighborhoods lacked transportation options to evacuate. In other regions the results are varied. A first ever global analysis by Winsemius et al. (2015) estimated a 'poverty exposure bias' to floods for 52 countries; i.e. that poor urban populations are often disproportionately represented in flood zones. Researching differential exposure to flood hazards in the UK, Houston et al. (2011) found that socially deprived areas are at slightly higher risk of pluvial flooding (rivers overtopping their banks), particularly in cities with larger rivers in which inner-city neighborhoods tend to be located in low-lying areas. Looking at New York City as a whole, Maantay and Maroko (2009) found that minority populations are not disproportionately represented in the 100-year floodplains, although in some boroughs (Manhattan, the Bronx, and Queens) African-Americans are disproportionately represented. In Cologne, Germany, results from an analysis by Welle et al. (2014) showed a low degree of spatial overlap between areas with high levels of flood exposure and those with high levels of social susceptibility, as measured by four metrics that examine household size and age composition, with an emphasis on the ability of residents to evacuate without assistance.

Other flood-related vulnerability assessments have been less tailored toward assessing differential exposure. Rygel et al. (2006) constructed a Social Vulnerability Index (SoVI) for the city of Norfolk, Virginia (United States), and surrounding areas known to be at high risk of coastal surge and sea level rise (SLR). While they experimented with alternative aggregation methods, they stopped short of assessing differential vulnerability to mapped distributions of flood hazards. Similarly, Kit et al. (2011) and Reckien et al. (2013) mapped slum distributions and flood hazards in Hyderabad, India; and Lane et al. (2013) examined indicators associated with higher flood vulnerability in the hurricane evacuation zones of New York City. Yet neither of these studies tested the hypothesis that populations exposed to floods or within these zones are more socially vulnerable than other populations.

There is a larger body of literature on differential exposure to urban heat stress, and most U.S.-based studies have found that poorer residents are exposed to higher temperatures than more affluent residents because low-income people are more likely to live in crowded conditions and older building stock, and/or live in neighborhoods with a lack of green space. An assessment of differential exposure to urban heat stress by Uejio et al. (2011) in Phoenix and Philadelphia found that heat distress calls in the former city and heat mortality in the latter city were correlated with higher proportions of minority residents and lower housing values. Other studies conducted in Philadelphia confirmed that the populations with high levels of social vulnerability also have relatively high levels of exposure to urban heat stress, as measured by satellite-derived land surface temperatures (Weber et al. 2015, Johnson and Wilson 2009). In a study of Washington, DC, Aubrecht and 
Özceylan (2013) created a heat stress vulnerability index (HSVI) composed of census-derived social vulnerability metrics and a heat stress risk index (HSRI), which is a combination of the HSVI and exposure to extreme heat. The HSRI was found to have high values in the poorer neighborhoods of northeast, east, and southeast Washington, DC; and particularly high values in Anacostia and Lincoln Heights, which are low-income, predominantly African-American neighborhoods south of the Anacostia River. De Sherbinin et al. (2012) conducted a spatial analysis of several cities using different poverty and heat/greenness metrics aggregated to high resolution census units. They found a positive correlation between median housing value and greenness in Phoenix, Arizona (greenness is negatively correlated with surface temperature (Imhoff et al. 2010)), and a slight positive correlation between income per capita and satellite-derived surface temperature in Houston, Texas.

In other regions, the evidence for differential exposure to heat stress is less clear. Romero-Lankao et al. (2013) analyzed temperature, air pollution, mortality, and socioeconomic vulnerability data for Bogota, Mexico City, and Santiago (Chile). They found little evidence that areas experiencing greater environmental stressors or health impacts were more likely to have populations with high levels of social vulnerability. In Cologne, Germany, results from an analysis by Welle et al. (2014) showed that there is a relatively high degree of spatial overlap between high heat exposure and lack of coping capacity (as measured by household size and residents' ages), but that there is little overlap with high levels of social susceptibility (as measured by unemployment rates and by the shares of the population who were very young, elderly, or foreign). De Sherbinin et al. (2012) found a positive correlation between poverty levels and vegetation greenness in Hanoi, Vietnam, and virtually no correlation between a multiple deprivation index produced by Baud et al. (2008) and satellite-derived surface temperature in Delhi. ${ }^{2}$

Although the existing literature is sparse, this brief review shows that the evidence on differential exposure by event type (flood or extreme temperatures) and by region is mixed.

\section{Overview of the two cities}

Over the past decade, New York City (NYC) and Mumbai have been hit hard by natural disasters. In the Mumbai metropolitan area at least 500 people died as a result of the July 2005 Maharashtra flash floods, which dumped more than $900 \mathrm{~mm}$ of rainfall on the city in a 24-hour period (Government of Maharashtra

2 One possible explanation for the differences between U.S. and developing region cities in exposure to heat stress is that higher-income residents have tended to remain in city center areas in many developing countries for ease of access to work and amenities, whereas the U.S. saw the flight of many upper-income populations to the suburbs from the 1950s onwards. 
2005). Hurricane Sandy caused 44 deaths in NYC in October 2012 (Goldstein 2013). Owing to their demographic and geographic characteristics, these two cities are among the top 10 port cities most exposed to coastal flooding in terms of the assets and the population exposed (Nicholls et al. 2008).

With a population of 8.25 million spread over five boroughs (about $785 \mathrm{~km}^{2}$ ), NYC has multiple waterways that create nearly $965 \mathrm{~km}$ of coastline affected by tides and weather. Though street and fluvial flooding affect NYC, coastal flooding represents the main danger. The massive coastal flooding during Hurricane Sandy caused extensive damage to NYC's infrastructure systems and coastal ecosystems, resulting in the loss of property and lives (Horton et al. 2015). Coastal flooding affects residential neighborhoods, businesses, infrastructure, coastal water quality (including sewage and toxic chemicals contamination), and natural ecosystems.

NYC has been a world leader in climate change adaptation planning. In 2008 the city launched the Climate Change Adaptation Task Force and the NYC Panel on Climate Change (NPCC) to develop adaptation strategies for protecting the city's infrastructure from the effects of climate change (Rosenzweig and Solecki 2010). In 2011, the city of New York updated PlaNYC, its plan to improve the city's sustainability, and particularly its resilience to and preparedness for extreme events (i.e. events projected to occur once every 100 years). Despite having identified its vulnerabilities (Horton et al. 2010, Jacob et al. 2007) and recently updated PlaNYC, the city still found itself unprepared for the 14-foot storm surge that occurred during Hurricane Sandy in October 2012 (Lane et al. 2013). A storm surge of this magnitude was considered to be a once-in-500-year event (Aerts et al. 2013).

Mumbai is at an earlier stage in the urban transition, and is facing many of the same environmental consequences of rapid economic growth and industrial expansion that the U.S. experienced six decades ago. Within the last three decades alone, metropolitan Mumbai's population has tripled, from eight million in 1991 to about 20.7 million in 2011 (Census of India 2011). Mumbai is largely located on reclaimed land, and much of the new settlement (industrial, residential, and commercial) has occurred along the coastal areas of Greater Mumbai that are lowlying and flood-prone (de Sherbinin et al. 2007). Although the metropolitan area of Mumbai extends well over $4,400 \mathrm{~km}^{2}$, population growth has largely been confined to $450 \mathrm{~km}^{2}$ in an area known as Greater Mumbai.

Over the years, topographic modifications, poor disaster planning, obsolete drainage systems, and poor coastal zone management have all exacerbated flood risk, thereby increasing the vulnerability levels of diverse sections of the population and of coastal ecosystems. In particular, the influx of migrant workers has led to the emergence of large informal settlements in low-lying areas (Parthasarathy 2009), where floods associated with extreme rainfall are highly damaging to human health and well-being, and thus compound existing vulnerabilities (Murthy et al. 2001, Dhage et al. 2006). Urban development is steadily encroaching on wetland ecosystems, which provide flood prevention and other important ecosystem services, while urban effluents often lead to hypoxic and anoxic conditions in coastal waters (Kumar et al. 2008). A study sponsored by the OECD modeled flood risks in 
Mumbai based on the July 2005 event (Ranger et al. 2011, Hallegatte et al. 2010). The team estimated the economic costs of the flood at USD 2 billion, and projected that under future development and climate scenarios the costs will triple. They also provided several adaptation options, including improving drainage and increasing insurance penetration.

Although the two cities have very different levels of economic development, both have a high degree of social stratification, which make them useful case studies for an assessment of differential vulnerability to flood hazards.

\section{Framework, data, and methods}

Our research is framed by the IPCC Special Report on Extreme Events (SREX) conceptual framework, which construes risk as emanating from the intersection of exposure to extreme events and social vulnerability (IPCC 2012). We measured social vulnerability using the approach described by Cutter et al. (2003) and Emrich (2011) for the construction of a Social Vulnerability Index (SoVI). The SoVI is commonly used in the literature to assess social vulnerability, but here we intend to use it as a synthetic measure of poverty and social exclusion to examine differential exposure to floods. The SoVI builds on research that has identified the primary social drivers of sensitivity to, and slow recovery from, natural hazards (Cutter et al. 2003, Carreño et al. 2007, Birkmann et al. 2011), including:

- Socioeconomic status (income, political power, prestige): Wealthy people are able to recover from natural disasters and absorb losses more quickly than poor people. Even if the total economic losses are higher for the richest people, the most deprived people face the greatest difficulties in recovering from these events.

- Gender: Women often face greater consequences and recover more slowly from natural disasters than men, due to factors such as their greater likelihood of being in sector-specific employment, having low wages, having family care responsibilities, or being pregnant. Single mothers in particular are threatened by natural hazards.

- Race, ethnicity, culture: Being part of an ethnic minority or foreign-born community can be helpful in the aftermath of a disaster if social solidarity exists. But in many circumstances being a member of minority group can result in social exclusion and difficulties in accessing government help, relocation, or funding because of isolation, lack of legal status, and low language proficiency.

- Age: Because they often suffer from health and mobility problems, the elderly are the most sensitive to disasters of all of the age groups (Al-rousan Tala et al. 2014). Early childhood is also a critical period. Children under age five are particularly vulnerable, and therefore require attention, time, and money from the whole family during both the disaster and the recovery process. 
- Housing stock: The quality of housing, as measured by rents, may indicate resilience to certain types of hazards.

- Family structure: Experiencing a catastrophe and the period of recovery that follows is especially difficult for those responsible for large families and for single-parent households.

- Education: Having a low level of education may constrain an individual's ability to understand warning information and access recovery information (Muttarak and Pothisiri 2013).

- Social dependence: People who are dependent on social services for survival require additional support in the post-disaster period.

- Special needs populations: Infirm, institutionalized, transient, drug-addicted, and homeless people are disproportionately affected during disasters. Because they are difficult to identify and measure, these populations are mostly ignored during the recovery phase.

Obviously, the factors that contribute to social vulnerability will differ depending on the stressor (e.g. floods, extreme heat, or air pollution), but this list covers a wide range of population factors that have been found to be important in vulnerability studies (Carreño et al. 2007, Birkmann et al. 2011). Other factors, such as the robustness of urban infrastructure, the existence of emergency services, and the adequacy of governance and institutions are all important in determining outcomes, but typically cannot be measured through census or survey data. There may also be location-specific factors that contribute to vulnerability, such as the existence of the caste system in India or of systematized gender discrimination.

Guided by these general factors and by the work of Cutter et al. (2003), we constructed Social Vulnerability Indices (SoVIs) in New York City and Mumbai based on available census data. The SoVI was originally developed to compare the hazard vulnerability of U.S. counties, but has been modified to allow for localscale analyses (Cutter et al. 2006, Schmidtlein et al. 2008) and applications of similar social vulnerability indices outside the U.S. (Fekete 2010, Crooks 2009, Confalonieri et al. 2009). The exposure aspects were measured using the available flood and flood risk data layers for each city. The specific indicators and flood data layers used in each city are described in greater detail in Sections 4.1 and 4.2. Here we provide information on the SoVI approach that is relevant to the two case studies.

The SoVI is calculated using principal components analysis (PCA). This approach uses eigen analysis to summarize the statistical properties of the indicators simultaneously by identifying a set of $n$ uncorrelated principal components (PCs), where $n=$ the number of indicators. The PCs are linear combinations of the indicators that are conceptually similar to a line of best fit through the data cloud. The first PC explains the greatest amount of variation in the $n$-dimensional data cloud; and the second PC explains the next largest amount of variation, subject to the constraint that it is orthogonal (or uncorrelated) to the first PC. Because the PCs are uncorrelated, the scores associated with each PC encapsulate a unique aspect of social vulnerability represented by the original set of indicators. SoVI scores can 
Figure 1:

Population by block group (quintiles)

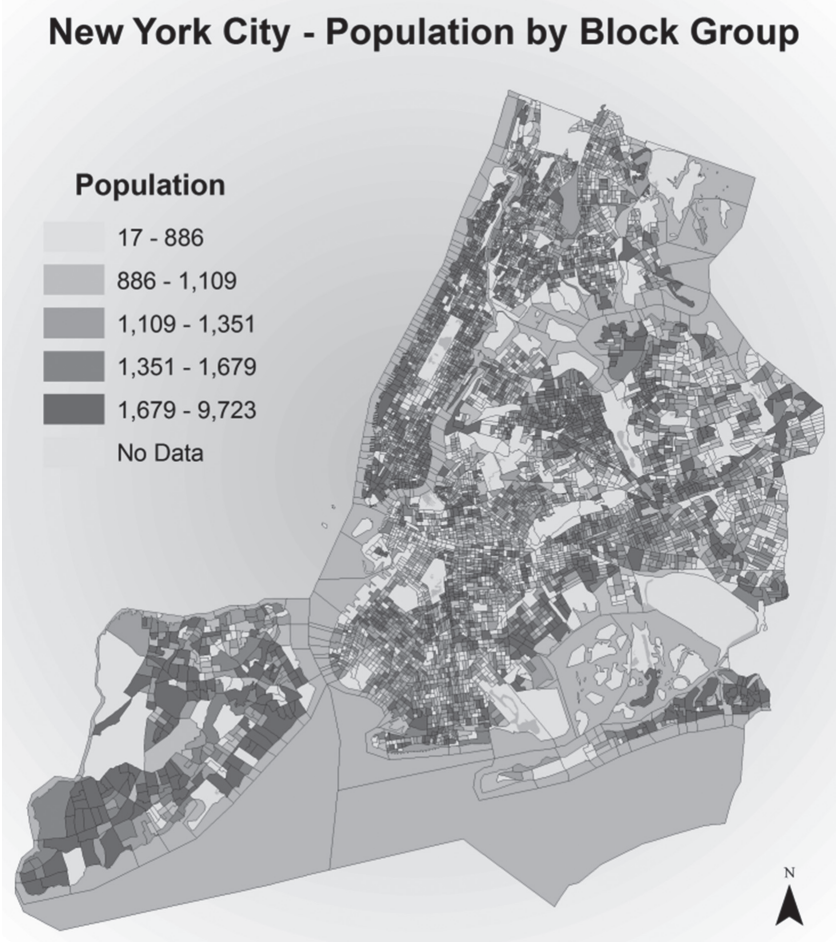

be interpreted as unit variance or z-scores; zero represents the mean, positive scores represent higher vulnerability, and negative scores represent lower vulnerability.

As suggested by the SoVI recipe (Emrich 2011) and Schmidtlein et al. (2008), we performed the PCA using a varimax rotation and only selected the components with an eigenvalue superior to one (Kaiser Criterion). Varimax rotation tends to load each variable highly on just one component in order to ease component interpretation (Schmidtlein et al. 2008). In both cities we named each of the PCs based on the indicators that loaded most highly on that PC. Demšar et al. (2013) discussed the merits of spatial PCA (sPCA), which takes into account spatial effects with respect to spatial heterogeneity or autocorrelation. We chose not to conduct a sPCA because 
it is not yet common practice to perform such an analysis in SoVI construction, ${ }^{3}$ and we were not convinced that doing so would have yielded significantly improved results, given that our main interest is in how the indicators co-vary over space.

It is a common practice to invert (reverse the directionality) of PCs by multiplying scores by -1 in cases in which higher values can be construed as being associated with lower vulnerability (Emrich 2011, Thornton et al. 2008). Once all of the PCs have the same directionality, they can be averaged together, with each PC given equal weight (which we call an 'Averaged SoVI'). Alternatively, a weighted average can be created in which each PC is multiplied by the variance it explains (which we call a 'Weighted SoVI'). Schmidtlein et al. (2011) stated that the SoVI algorithm does not appear to be substantially influenced by scalar changes, but is sensitive to variations in its construction. The SoVIs we constructed are obviously influenced by the choice of variables and the aggregation method, but a comparison using different approaches to SoVI construction suggested that the results were broadly similar.

In each city, we compare SoVI scores within different flood exposure categories, and in the case of New York, evacuation zones. For each exposure category we calculated a population weighted mean of the Average and the Weighted SoVIs. Figure 1 shows the population by block group. The population-weighted SoVI avoids the potential problem that block groups with very low populations could have a disproportionate influence on the average score by exposure category; since our concern is with the exposure of populations, it is appropriate to apply the population weight using the following formula:

$$
\mathrm{SoVI}_{Z}=\sum_{i=1}^{n}\left(\mathrm{SoVI}_{i} * \mathrm{P}_{i}\right) /\left(\sum_{i=1}^{n} \mathrm{P}_{i}\right)
$$

Where:

$\mathrm{SoVI}_{Z}=$ SoVI population-weighted score for the zone $Z$ (exposure category), $\mathrm{SoVI}_{i}=\mathrm{SoVI}$ of the $i$ block

$\mathrm{P}_{i}=$ Population of the $i$ block

With these population-weighted means, we were able to test whether there is a statistically significant difference in the mean scores by exposure category for each of the two cities.

In line with Winsemus et al. (2015) we also tested an additional metric, the 'poverty exposure bias' (PEB), which compares the fraction of the poor population with the fraction of the total population exposed to floods in each city. This summary metric, while not as sophisticated, provides an additional test of differential exposure.

3 We were unable to find a single SoVI analysis that used sPCA. Indeed, Demšar et al. reported that "in surveyed literature we found proportionally few studies that use spatially adapted versions of PCA to analyze their data" (p. 123). 


\subsection{New York}

\subsubsection{New York social vulnerability}

For New York, we began with a list of relevant variables published on the Hazards and Vulnerability Research Institute's SoVI website ${ }^{4}$ (USC undated), but modified the list based on their applicability to the NYC context and flood vulnerability. The choice of variables is obviously important, since not all variables are directly relevant to every type of hazard (Welle et al. 2014). We chose a somewhat liberal approach to the construction of the SoVI for flood exposure, but also tested the importance of individual variables with stronger theoretical ties to flood exposure to see if the results differed substantially. Table 1 provides a list of the variables we removed and our reasons for removing them. We used data from the 2010 U.S. Decennial Census and five-year estimates from the 2006-2010 American Community Survey. The U.S. Decennial Census covers the entire American population on years ending with ' 0 ', and includes a reduced set of variables. The American Community Survey (ACS) is an ongoing statistical survey that gathers information on about one in 38 households every year. The Census Bureau releases estimates based on one, three, and five years of data. As recommended on the SoVI website, we used data from the ACS five-year estimates for 2006-2010 because they are more robust and better match the decennial census data. In cases in which the data existed in both datasets, we selected the census data, as they represent a full count and not an estimate.

We recognize that the uncertainty levels in the three-year ACS data are very high at smaller geographies, such as block groups and census tracts (Spielman et al. 2014, Bazuin and Frazier 2013). Thus, we believe that the use of a mix of decennial census variables, five-year estimates, and a relatively large number of variables mitigates the risk of spurious results. Roughly two-thirds (13 out of 21) of the variables were obtained from the decennial census, and seven out of 11 of the variables that were found to be most highly correlated with the top five PCs (and therefore contributed most to the SoVI scores) were from the decennial census.

We collected data at the block group level for both the census and the ACS, which is the smallest unit at which data are reported. The data were from three websites: American Fact Finder, Social Explorer, and Data Ferret. ${ }^{5}$ The average population of a block group in NYC is 1,300 inhabitants, and there were 6,198 block groups covering the city's five boroughs, for a total population of approximately 7.8 million people. Table 2 provides the list of the variables we selected together with the broad category, the origin of the data, and the effect on the SoVI.

4 The SoVI was developed by Susan Cutter and colleagues at the Hazards and Vulnerability Research Institute.

5 http://factfinder.census.gov/, http://www.socialexplorer.com/ and http://dataferrett.census.gov/, respectively. 
Table 1:

Discarded variables from the SoVI

\begin{tabular}{ll}
\hline Variables removed & Reason \\
\hline $\begin{array}{l}\text { Percent Urban Population } \\
\text { Percent Employment in Extractive }\end{array}$ & Not pertinent in a city, and very low variability \\
Industries (e.g. mining) & Not pertinent in a city, and very low variability \\
Percent Employment in Services & \\
Median Housing Value & Not theoretically relevant to flood exposure \\
Median Gross Rent & Too many missing values at block group level \\
Percent Mobile Homes & Data not consistent at block group level \\
Percent Civilian Unemployment & Not pertinent in a city, and very low variability \\
Hospitals Per Capita & Data not available at block group level \\
Percent of Population Without Health & Data not available at block group level \\
$\quad$ Insurance & Data not available at block group level \\
\hline
\end{tabular}

The variables were normalized where necessary by transforming raw figures into comparable indicators, such as percentage of population or density. We analyzed the data while focusing on the following: (1) the level of reliability and confidence in the datasets (e.g. the estimations we had on housing prices were not reliable at our block group scale); (2) the correlation among variables, discarding those that are too highly correlated (if two variables cover the same information we do not need both); and (3) removing block groups without data, such as parks and industrial areas, or block groups without housing units (e.g. the Rikers Island jail complex). The result was a single file with 21 variables and 6,199 block groups. A correlation/covariance matrix for all of the variables is found in Tables A.1 and A.2 in the appendix. Finally, we performed the PCA as described in above, and we extracted five factors explaining a total of $71.1 \%$ of the variance of our original dataset (see Table 3). We inverted Factor 5, and then developed averaged and weighted SoVI scores, which are shown in Figure 2. The results are broadly similar.

Examining Figure 2, we can see that the most vulnerable block groups are often located together, forming large socially vulnerable areas.

- The eastern part of Brooklyn (Bushwick, Bedford-Stuyvesant, East Flatbush, Brownsville, Canarsie or East New York)

- Northern Manhattan and a large part of the Bronx

- Southeastern Manhattan (Chinatown and the Lower East Side)

- Coney Island and Brighton Beach

- Downtown Flushing in northern Queens

By contrast, most of Staten Island, the southern half of Manhattan (except the Lower East Side neighborhoods) and southeastern Queens have very low SoVIs, and thus show low levels of social vulnerability to climate extremes. 
Table 2:

List of variables used for New York's SoVI

\begin{tabular}{|c|c|c|c|}
\hline Variable & Category & Origin & $\begin{array}{c}\text { Effect } \\
\text { on SoVI }\end{array}$ \\
\hline Percent Black & Race/Ethnicity & Census & + \\
\hline Percent Native American & Race/Ethnicity & Census & + \\
\hline Percent Asian & Race/Ethnicity & Census & + \\
\hline Percent Hispanic & Race/Ethnicity & Census & + \\
\hline $\begin{array}{l}\text { Percent of Population Under Age } 5 \text { or } \\
\text { Over Age } 65\end{array}$ & Age & Census & + \\
\hline $\begin{array}{l}\text { Percent of Children Living in Married } \\
\text { Couple Families }\end{array}$ & Family Structure & Census & - \\
\hline Median Age & Age & Census & + \\
\hline $\begin{array}{l}\text { Percent of Households Receiving Social } \\
\text { Security }\end{array}$ & Age, Dependency & ACS & + \\
\hline Percent Poverty & Income & ACS & + \\
\hline $\begin{array}{l}\text { Percent of Households Earning More } \\
\text { Than } \$ 200,000 \text { Annually }\end{array}$ & Income & ACS & - \\
\hline Per Capita Income & Income & ACS & - \\
\hline $\begin{array}{l}\text { Percent Speaking English as a Second } \\
\text { Language with Limited Proficiency }\end{array}$ & Race/Ethnicity & ACS & + \\
\hline Percent Female & Gender & Census & + \\
\hline Percent Female-Headed Households & Gender, Family Structure & Census & + \\
\hline $\begin{array}{l}\text { Percent of Population Living in Nursing } \\
\text { and } \\
\text { Skilled-Nursing Facilities }\end{array}$ & Age, Dependency & Census & + \\
\hline $\begin{array}{l}\text { Percent with Less Than 12th Grade } \\
\text { Education }\end{array}$ & Education & ACS & + \\
\hline $\begin{array}{l}\text { Population Density (Population per } \\
\text { Square Mile) }\end{array}$ & Urbanization & Census & + \\
\hline People per Housing Unit & Family Structure & Census & + \\
\hline Percent Renters & Income, Tenancy & Census & + \\
\hline Percent of Housing Units with No Car & Income, Urbanization & ACS & + \\
\hline
\end{tabular}

\subsubsection{New York flood exposure}

For New York we used two different maps: an Evacuation Zones map released by New York City's Office of Emergency Management (06/20013), and the Hurricane Sandy Impact Analysis by the Federal Emergency Management Agency (FEMA) Modeling Task Force (MOTF), which highlights the areas flooded by Sandy (Figure $3 a$ and $b$ ).

Figure 3a shows the evacuation map as issued by FEMA. The zones determine when an area has to be evacuated, with zone 1 being the first (relatively weak flooding) and zone 6 being the last (a very strong event). We intersected this map 
Table 3:

Principal components of New York's SoVI

\begin{tabular}{|c|c|c|c|c|c|}
\hline Factor & Name & $\begin{array}{l}\text { Variance } \\
\text { explained }\end{array}$ & Principal variables & Correlation & Sign \\
\hline 1 & Poverty & $17.4 \%$ & $\begin{array}{l}\text { Per Capita Income } \\
\% \text { Earning } \$ 200,000+\end{array}$ & $\begin{array}{l}-0.849 \\
-0.894\end{array}$ & + \\
\hline 2 & Dense Urbanization & $16.3 \%$ & $\begin{array}{l}\% \text { with No Car } \\
\% \text { Renters } \\
\text { Population Density }\end{array}$ & $\begin{array}{l}0.879 \\
0.794 \\
0.766\end{array}$ & + \\
\hline 3 & $\begin{array}{l}\text { Black and Single } \\
\text { Parent Households }\end{array}$ & $15.8 \%$ & $\begin{array}{l}\% \text { Black } \\
\% \text { Female-Headed Households } \\
\% \text { Children in Married-Couple } \\
\quad \text { Families }\end{array}$ & $\begin{array}{r}0.838 \\
0.800 \\
-0.723\end{array}$ & + \\
\hline 4 & Age & $11.9 \%$ & $\begin{array}{l}\text { \% Under Age } 5 \text { or Over Age } 65 \\
\text { Median Age }\end{array}$ & $\begin{array}{l}0.891 \\
0.753\end{array}$ & + \\
\hline 5 & Hispanic & $11.8 \%$ & $\begin{array}{l}\text { Percent Hispanic } \\
\text { Percent Native American }\end{array}$ & $\begin{array}{l}0.745 \\
0.758\end{array}$ & + \\
\hline
\end{tabular}

Figure 2:

Weighted SoVI (left) and Averaged SoVI (right) for New York (quintiles)
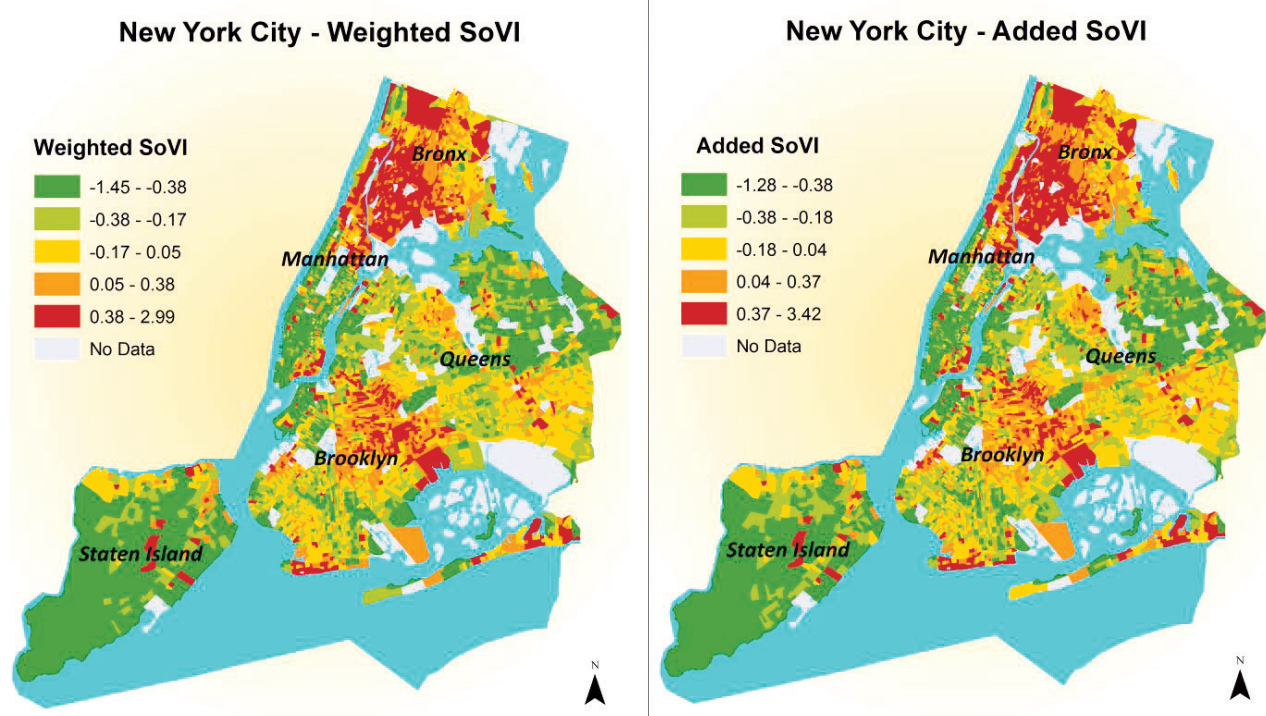
Figure 3:

(a) Evacuation zones and (b) Sandy flooding extent maps, New York

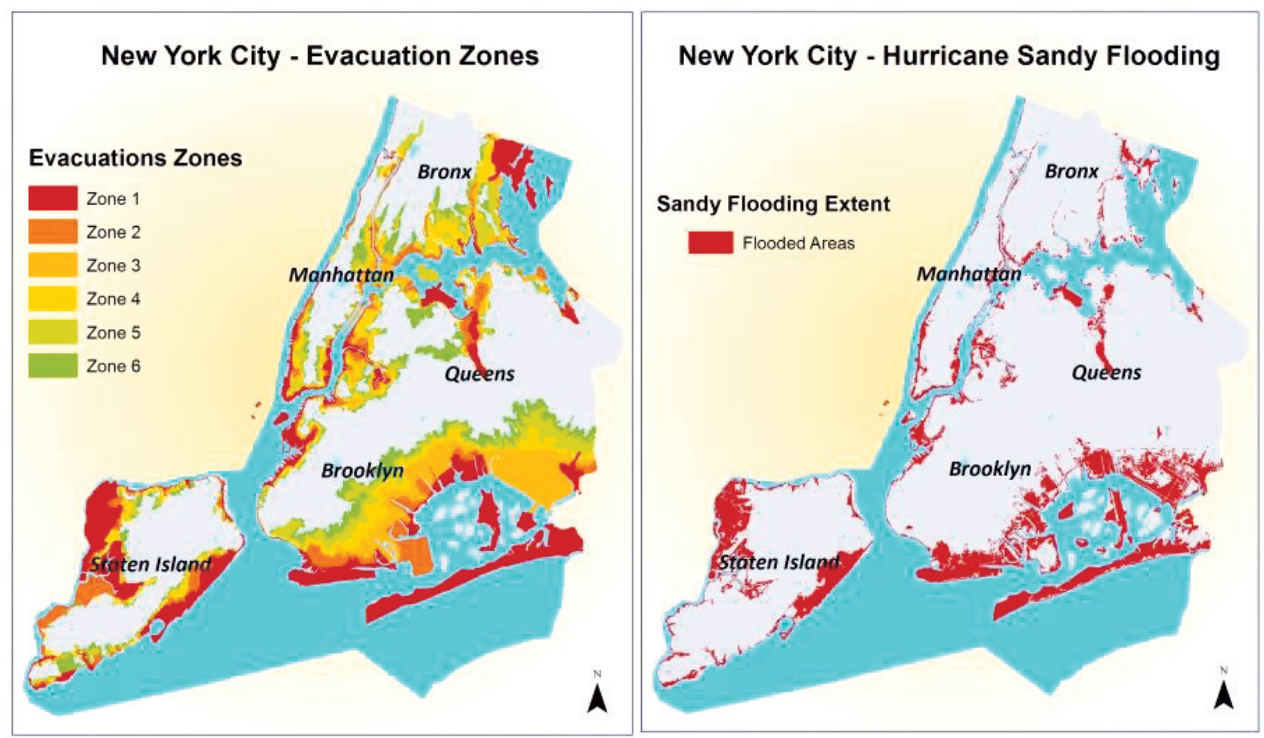

with the block group boundaries base map in order to give an 'evacuation score' to each block group. This score was assigned to the block group based on the proportion of the block group that fell in the zone (majority rule). We reclassified the evacuation zones such that each block group fell into one of the seven categories, moving from lowest to highest risk. Category A represents block groups not in any evacuation zone, and categories B-G represent those in the lowest flood risk category (zone 6) to those in the highest category (zone 1). We included the evacuation zones because Sandy was a singular event with flood impacts that were determined by the specific meteorological conditions that produced it. The evacuation zones represent a broader risk assessment for hurricanes with multiple trajectories, wind speeds, and locations of landfall.

Figure $3 b$ represents the area covered by Hurricane Sandy flooding in NYC. Here we created a 'flooding score' for each block group, and separated them into four categories. Category A represents block groups outside of the flooding zone (77.5\% of all block groups). Using quantiles (7.5\% each) we divided the remaining block groups as follows: category B was $0.01-13.5 \%$ flooded, category $\mathrm{C}$ was $13.6-$ $50 \%$ flooded, and category D was 50-100\% flooded. We were thus able to compare the social vulnerability levels based on both a theoretical (evacuation) score and a factual exposure (flooding) score. 
Table 4:

Mumbai SoVI variables

\begin{tabular}{lcc}
\hline Variables & Category & Effect on the SOVI \\
\hline Population Density & Urbanization & + \\
\% Female & Gender & + \\
\% Under Age 6 & Age & + \\
\% Scheduled Tribes or Castes & Race/Ethnicity & + \\
\% Literacy & Education & - \\
\% Slum Population & Income & + \\
\% Workers Among Females & Gender & - \\
\% Unemployment & Social Exclusion & + \\
\% of Households Using Bank Services & Social Exclusion & - \\
\% of Households with a TV & Income & - \\
\% of Households with a Motorcycle & Income & - \\
\% of Households with a Car & Income & - \\
\hline
\end{tabular}

\subsection{Mumbai}

\subsubsection{Mumbai social vulnerability}

Up-to-date, high-resolution census data for Mumbai were much more difficult to obtain, and matching boundary files had to be obtained from third parties. The Indian census provides relatively good-quality, recent (2011), and easy-to find data at a country, state, or city level. But it was impossible to locate more spatially resolved data for city-level analyses. Ultimately we settled on data from the 2001 census for 99 wards (average of 120,000 inhabitants/ward), and selected 12 variables that fit the factors that contribute to vulnerability, as described in the introduction to section 4 (Table 4). We believe that the 2001 data are reasonably representative of conditions at the time of the Mumbai Floods.

We performed a PCA, and obtained three components representing $76.4 \%$ of the total variance (Table 5). Again, we created an averaged and weighted (by percentage variance explained) SoVI. Figure 4 presents a map of the results.

The results show that, as expected, the wealthy Mumbai City District, located in the southern part of the city, is the least vulnerable. The highest SoVI scores are concentrated in the eastern and northwestern sections of the city. In Mumbai the central business district is relatively prosperous, while the northern parts of the city are dominated by poorer populations who either work locally or commute to the business district by train. The northern sections are also home to some of the most densely populated slums in the world. 
Table 5:

Principal Mumbai components extracted by PCA

\begin{tabular}{llllll}
\hline Factor & Name & $\begin{array}{c}\text { Variation } \\
\text { explained }\end{array}$ & Principal variables & Correlation & Sign \\
\hline $\mathbf{1}$ & $\begin{array}{c}\text { Standard of life } \\
\text { and } \text { access to } \\
\text { information }\end{array}$ & $42.1 \%$ & $\begin{array}{l}\text { \% Households Using Bank } \\
\text { Services }\end{array}$ & $\mathbf{0 . 9 5}$ & - \\
& & & $\begin{array}{l}\% \text { Households with TV } \\
\text { \% Literacy }\end{array}$ & $\mathbf{0 . 9 4}$ & \\
& Employment & $17.8 \%$ & \% Unemployment & $\mathbf{0 . 9 0}$ & + \\
$\mathbf{2}$ & Female employment & $16.5 \%$ & $\%$ Workers Among Females & $\mathbf{0 . 8 9}$ & - \\
\hline
\end{tabular}

\subsubsection{Mumbai flood exposure}

We obtained data from Ranger et al. (2011) and Hallegatte et al. (2010), in which they modeled the flood extent associated with the July 2005 flood (Figure 5). The data are derived from relatively coarse-resolution digital elevation models using NASA Shuttle Radar Topography Mission data, and once again do not match the resolution of the data that we had available for NYC.

\subsubsection{Mumbai data limitations}

While the SoVI maps give a sense of the overall distribution of social vulnerability levels within the city, it should be emphasized that the ward scale is not accurate enough to depict Mumbai's complex realities, as a single ward can contain both rich neighborhoods and slums. At this scale of analysis it is tempting to commit the ecological fallacy of assuming a degree of homogeneity within units that does not exist. Furthermore, there are far fewer variables available for Mumbai than for NYC, which limits the flood-relevance of the analysis. In particular, for Mumbai we lack age structure data that would permit the construction of an under-five and over65 indicator similar to the indicator created for New York. Finally, while the census data of 2001 may reflect realities at the time of the flood event, they are clearly dated for a city that is evolving so rapidly.

On the exposure side, the exposure data were modeled based on relatively coarseresolution elevation models, and because the flood polygons represent an extremei.e. a once-in-200-year event (Hallegatte et al. 2010) - they cannot be seen as representative of more typical flooding patterns. 
Figure 4:

Weighted SoVI scores, 5 quintiles

\section{SoVI Mumbai - 2001 Data}
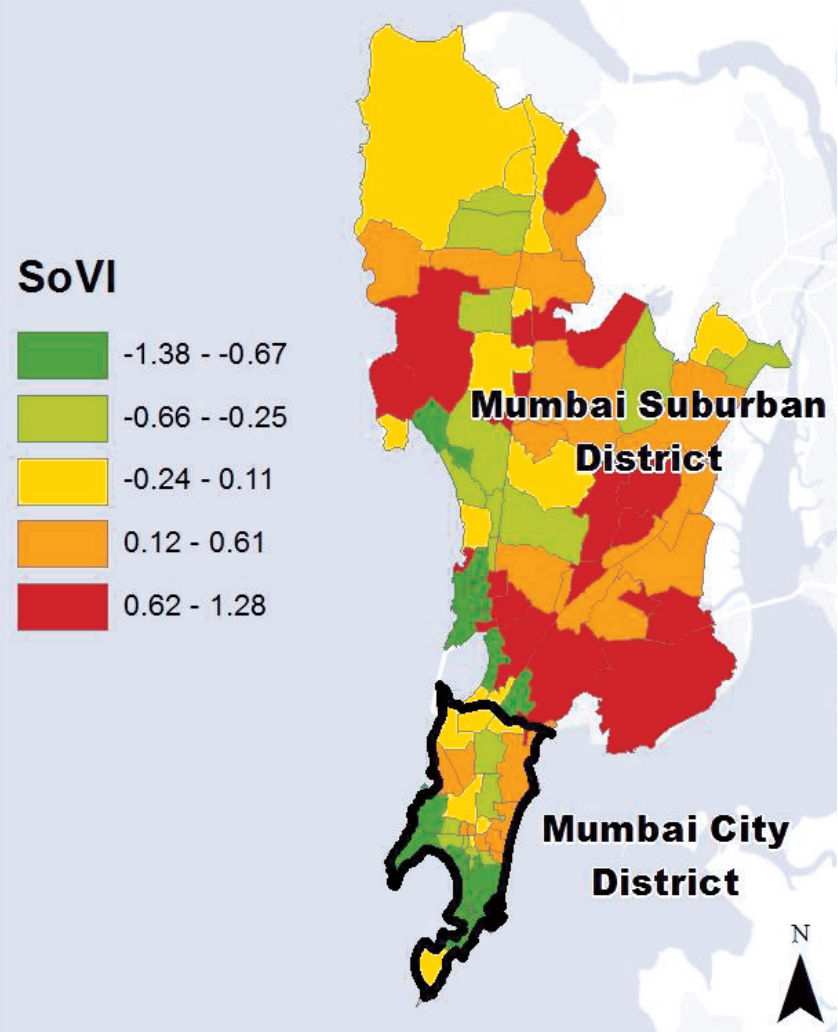

Copyright: @2013 Esri, DeLorme, NAVTEC

\section{Results}

\subsection{New York City}

For New York City the average SoVI scores by evacuation category are in Table 6, and the average SoVI scores by proportion of block group flooded are in Table 8 . We also provide average values for the indicators that have been found to be particularly relevant to flood vulnerability assessment in Tables 7 and 9. The difference in means are all significant at the $\mathrm{p}<0.01$ level or higher. The fact that all but a few of the categories have above-average SoVI scores $(>0)$ is a reflection 
Figure 5:

Digitized flood extent map for the 2005 event (data courtesy Ranger et al. 2011)

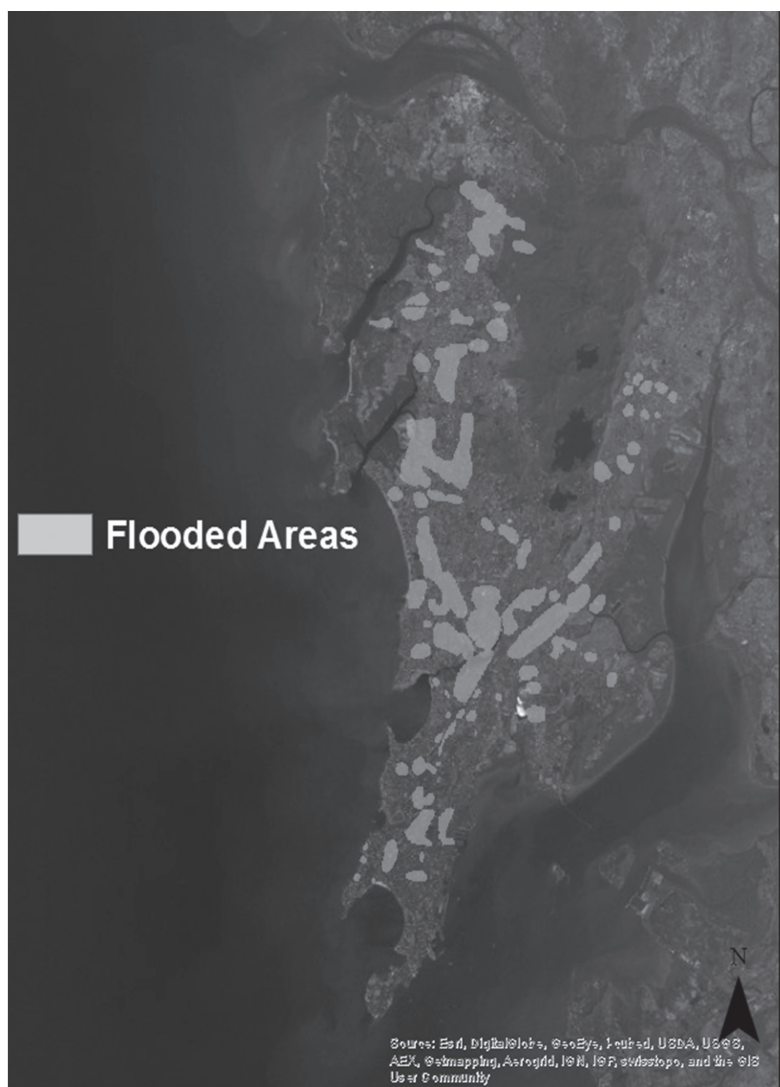

of the population-weighting; densely populated block groups have higher SoVI scores. ${ }^{6}$ A separate analysis in which the mean SoVI scores were calculated without population weighting resulted in more SoVI scores below the mean in several exposure categories.

The results provide only limited support for the differential exposure hypothesis. The SoVI scores are the same in the most flooded (category D) and the nonflooded (category A) areas. Flood category A's high scores probably reflect the high concentrations of poverty in Harlem and the Bronx, which are located farther from the coast and at higher elevations. The SoVI scores are highest in the highest risk evacuation zone, but are lowest (and nearly inverted) in the next-highest risk zone,

6 The Pearson's $r$ between population density and SoVI scores is $0.35(\mathrm{p}<.0001)$. 
Table 6:

NYC SoVI averages for evacuation categories

\begin{tabular}{lcc}
\hline Category & Weighted SoVI & Averaged SoVI \\
\hline A (no evacuation) & 0.02 & 0.02 \\
B (low risk) & 0.02 & 0.01 \\
C & 0.04 & 0.03 \\
D & 0.05 & 0.04 \\
E & 0.07 & 0.05 \\
F & -0.08 & -0.09 \\
G (high risk) & 0.08 & 0.09 \\
\hline
\end{tabular}

Table 7:

NYC averages of individual indicators for evacuation categories (high values in bold)

\begin{tabular}{|c|c|c|c|c|c|}
\hline Category & $\begin{array}{c}\% \text { Population } \\
\text { aged } \\
<5 \text { and }>65\end{array}$ & $\begin{array}{l}\% \text { Population } \\
\text { in poverty }\end{array}$ & $\begin{array}{c}\text { \% of Pop } \\
\text { with less than } \\
\text { 12th grade education }\end{array}$ & $\begin{array}{c}\text { \% Female } \\
\text { headed } \\
\text { Households }\end{array}$ & $\begin{array}{c}\% \\
\text { Black }\end{array}$ \\
\hline A (no evacuation) & 18.6 & 18.5 & 21.6 & 39.4 & 23.9 \\
\hline B (Zone 6) & 17.9 & 19.6 & 21.9 & 40.6 & 25.8 \\
\hline C (Zone 5) & 18.4 & 18.6 & 21.1 & 41.3 & 31.0 \\
\hline D (Zone 4) & 18.4 & 17.4 & 20.0 & 41.8 & 30.7 \\
\hline E (Zone 3) & 19.2 & 18.2 & 19.2 & 42.1 & 32.8 \\
\hline F (Zone 2) & 18.9 & 14.4 & 18.3 & 38.4 & 23.2 \\
\hline G (Zone 1) & 22.0 & 17.4 & 19.4 & 39.6 & 19.5 \\
\hline
\end{tabular}

Table 8:

NYC SoVI averages for flooding categories

\begin{tabular}{lcc}
\hline Category & Weighted SoVI & Averaged SoVI \\
\hline A (0\% flooded) & 0.03 & 0.03 \\
B (0.01-13.5\% flooded) & -0.08 & -0.07 \\
C (13.6-50\% flooded) & -0.03 & -0.02 \\
D (50-100\% flooded) & 0.03 & 0.03 \\
\hline
\end{tabular}

the largest spatial area of which is found in southern Brooklyn, northwestern Staten Island, and the more prosperous parts of Queens.

The age dependency variable shows relatively consistent results across all of the evacuation and flood risk categories except the highest evacuation and flood risk 
Table 9:

NYC averages of individual indicators for flooding categories (high values in bold)

\begin{tabular}{|c|c|c|c|c|c|}
\hline Category & $\begin{array}{c}\% \text { Population } \\
\text { aged } \\
<5 \text { and }>65\end{array}$ & $\begin{array}{l}\text { \% Population } \\
\text { in poverty }\end{array}$ & $\begin{array}{c}\text { \% of Pop } \\
\text { with less than } \\
\text { 12th grade education }\end{array}$ & $\begin{array}{c}\% \text { Female } \\
\text { headed } \\
\text { Households }\end{array}$ & $\begin{array}{c}\% \\
\text { Black }\end{array}$ \\
\hline $\begin{array}{l}\text { A }(0 \% \\
\text { flooded })\end{array}$ & 18.4 & 18.9 & 21.7 & 40.3 & 26.4 \\
\hline $\begin{array}{c}\text { B (0.01-13.5\% } \\
\text { flooded })\end{array}$ & 19.4 & 16.2 & 17.5 & 37.9 & 22.5 \\
\hline $\begin{array}{c}\text { C }(\mathbf{1 3 . 6 - 5 0 \%} \\
\text { flooded) }\end{array}$ & 19.0 & 15.9 & 18.6 & 40.0 & 22.6 \\
\hline $\begin{array}{c}\text { D }(50-100 \% \\
\text { flooded })\end{array}$ & 21.5 & 16.1 & 18.6 & 38.8 & 21.0 \\
\hline
\end{tabular}

categories, where there is a $\sim 2$ percentage-point higher dependency. This finding may suggest there are greater numbers of retirees or young families living on the waterfront, although without more data this remains a hypothesis. By contrast, the other social vulnerability indicators are all highest for flood category A. Similarly, for zone 1 there is a significantly higher age dependency, but the other indicators show no discernible pattern.

We tested for the PEB, setting two thresholds: $>30 \%$ and $>50 \%$ block group area flooded. Our aim was to determine whether the fraction of the poor population exposed to Hurricane Sandy flooding was higher than the fraction of the total population. We found that almost exactly the same proportion of the poor population and the total population were flooded in both groups: $\sim 0.08$ of the total population and 0.07 of the poor population experienced $>30 \%$ flooding, and 0.06 of the total population and 0.05 of the poor population experienced $>50 \%$ flooding. These results do not support the differential exposure hypothesis.

\subsection{Mumbai}

We used the 2005 flooding extent maps to compare average SoVI scores to exposure. We created four categories: category $\mathrm{A}$ is made up of non-flooded wards, and categories B to D consist of wards from the least to the most flooded by proportion area; again divided into equal intervals. We then applied the difference in means analysis to obtain Table 10. As we did in presenting the NYC results, we provide average values for indicators that were found to be particularly relevant to flood vulnerability assessment in Table 11, reporting only those indicators for which the differences in means are significant at the $p<0.10$ level or higher (two indicators, percentage population scheduled castes or tribes and percent population $<6$, did not have statistically significant results). 
Table 10:

Mumbai SoVI averages for flooding categories

\begin{tabular}{lcc}
\hline Category & $\begin{array}{c}\text { Weighted SoVI } \\
\text { (results not significant) }\end{array}$ & Averaged SoVI \\
\hline A (no flood) & 0.14 & 0.19 \\
B (low flood) & 0.34 & 1.00 \\
C (med. flood) & 0.25 & 0.80 \\
D (high flood) & 0.29 & 0.95 \\
\hline
\end{tabular}

Table 11:

Mumbai average indicator scores by flooding categories (high value in bold)

\begin{tabular}{lcc}
\hline Category & \% Slum population & $\begin{array}{c}\text { \% Households with } \\
\text { a television }\end{array}$ \\
\hline A (no flood) & 21.7 & 70.3 \\
B (low flood) & 41.5 & 76.7 \\
C (med. flood) & 43.9 & $\mathbf{7 9 . 4}$ \\
D (high flood) & $\mathbf{4 9 . 3}$ & 75.6 \\
\hline
\end{tabular}

Overall, the Averaged SoVI scores are higher for each flood category than in New York. The highest scores are for the added SoVI across all flooded areas. The Weighted SoVI gives more importance to factor 1 (access to information; $42.6 \%$ of variance explained), and generally results in lower SoVI scores across all of the flooded categories than the Averaged SoVI. Furthermore, the difference in means is not significant. In both cases, the main observation is that the wards with no flooding are always the least vulnerable for each type of SoVI. This analysis generally confirms our hypothesis that the socially vulnerable wards were more affected by the July 2005 flash floods; or at a minimum that the least-exposed wards had the lowest levels of social vulnerability. While the results are interesting, and suggest tentative support for the differential exposure hypothesis, we would require higher resolution census data and more spatially explicit flood maps to conclusively confirm the hypothesis.

We also tested for the PEB. Since 78 of 99 wards experienced at least some flooding, we set three thresholds $->10 \%,>30 \%$ and $>50 \%$ of the ward area flooded - to determine whether the fraction of the slum population exposed to the flood was higher than the fraction of the total population. We found that almost exactly the same shares of the slum population and of the total population were found in wards that were $>10 \%$ and $>30 \%$ flooded $(\sim 0.72$ and 0.31 , respectively, for the slum and the total population), whereas marginally higher fractions of the slum population 
were found in the wards that were $>50 \%$ flooded ( 0.185 of the slum population versus 0.155 of the total population). These results provide only limited evidence to support the differential exposure hypothesis.

\section{Discussion and conclusion}

In the case of New York, our study provides only limited support for the hypothesis that the most socially vulnerable are differentially exposed to flood hazards. For Mumbai, we find stronger support for this hypothesis, but we also acknowledge the data limitations. Our results are tentative for a number of reasons. First, while the differences in means are statistically significant, the actual differences in SoVI scores are often quite small. But there are also broader data and methodological challenges. Here we discuss the limitations of this study, which are broadly applicable to urban spatial vulnerability assessments in three areas: uncertainty, spatial resolution, and the use and limitations of aggregate indices such as the SoVI.

In the United States there are large margins of error in the ACS data at the block group level, and there are arguments for using data at the census track level (Spielman et al. 2014, Bazuin \& Frazier 2013), even though there is a loss in spatial precision when units are overlaid on exposure categories. ${ }^{7}$ Thus, the highest resolution units introduce uncertainty owing to the small household sample sizes. At the other extreme, many developing countries provide data at highly aggregated levels only, often without matching spatial boundary layers. The data for Mumbai are so highly aggregated and so infrequently updated that their use introduces other forms of uncertainty; namely, that the large units mask major sub-unit spatial variability in population characteristics, and that the infrequent updates inadequately capture changes in highly dynamic urban populations.

These issues are indicative of a general problem that arises in urban climate vulnerability assessments conducted in developing countries: there is a need for higher resolution, regularly updated spatial data for both exposure and the exposed elements (Martine and Schensul 2013). For the exposure estimates, the flood extents we used were reasonably accurate for New York, whereas for Mumbai the flooded areas were modeled based on fairly coarse-resolution satellite-derived digital elevation models. For the exposed elements, we were able to obtain for NYC census data for more than 6,198 block groups averaging $\sim 1,000$ inhabitants, but for Mumbai we were only able to obtain data for 99 wards averaging $\sim 120,000$ inhabitants. The lack of access to high-resolution census data in many developing countries obviously limits the spatial precision of vulnerability assessments. Dasymetric mapping, in which relatively coarse-resolution population inputs are redistributed based on ancillary data (e.g. information on slopes or parklands), is increasingly being employed to model population distributions at

7 There are 4,336 census tracts in New York City, as opposed to 6,198 block groups. 
higher levels of spatial resolution (Mantaay et al. 2009). Yet the process involved in this type of mapping is time consuming, and not without its own technical challenges. Moreover, it less evident how we can spatially disaggregate population characteristics (as opposed to population counts).

There are also temporal dimensions to uncertainty. Our research is retrospective and does not necessarily represent the present reality (at least in Mumbai, a dynamic city for which the only available data were from 2001) or likely future patterns, as flood and storm surge risks are intensifying as the climate changes (IPCC 2012). Forecasting flood extents may be possible using standard modeling techniques (e.g. Storch et al. 2011), but predicting future social vulnerability is much harder. Forecasting future risks and vulnerabilities for cities and communities is becoming increasingly important for the design of adaptation interventions. There are incipient efforts to use big data sources, such as mobile phone recharge rates or satellite data, to provide more real-time estimates of poverty for climate resilience, but this area of research has not yet reached a high level of maturity.

Turning to the issue of aggregate indices, we note that the SoVI itself, like all PCA-based methods, is driven by the statistical relationships between the indicators, and not by theory (Abson et al. 2012). Thus, the most important indicators from a theoretical perspective, or those used to assess susceptibility to floods (e.g. percent of population aged $>65$ ), may influence the overall results the least, especially if there are few covariates. It is also possible that some of the variables that theoretically predict greater harm (health, economic, or mortality impacts), such as the percentage of the population who are elderly, may not correlate with actual outcomes. This might be the case, for example, if the elderly are well off and have the means to escape easily (i.e. a car or a second home). While we feel that our process for identifying variables was robust, given the low levels of mortality or other outcome measures, we could not identify which factors best predicted that outcome variable. In post-Sandy surveys, Madajewic and Coirolo (2015) found that poverty levels were rather poor predictors of losses. In the wake of Hurricane Sandy, those who suffered the greatest impacts (economic losses) were middle-income homeowners, whereas renters in lower socioeconomic brackets were able to move out of the area, avail themselves of social services, and recover rather quickly. We do not have as much evidence for Mumbai, but broadly it seems that despite the severity of the flood, mortality levels were limited owing to self-help networks such as slum dweller associations (de Sherbinin et al. 2007). In both cases, it is clear that there is a need for more targeted data collection efforts post-event to determine where the greatest vulnerabilities lie. In turn, these data can help to refine the 'global' models, such as the SoVI, which can cover broad areas using census-derived metrics.

In terms of policy relevance, this work contributes to the broader environmental justice literature that investigates the extent to which poorer populations are disproportionately exposed to hazards. The effect of climate extremes on exposed populations is the stuff of weekly headlines. As we noted earlier, we are not only likely to see more extreme weather events in the future (IPCC 2012), but many of today's extreme events can be attributed to climate change (James 2015, Herring 
et al. 2014). Yet assessing the environmental justice aspects of climate extremes is in many ways more challenging, partly because climate change impacts are a more evenly distributed 'public bad' than, for example, toxic waste sites; and partly because there is uncertainty about the location of future impacts.

As we discussed in the introduction, there are theoretical reasons to suppose that poorer populations may be disproportionately located in flood zones if those zones are characterized by lower rents. But there are also reasons to suppose that wealthier populations may be drawn to locations along shorefronts and rivers because of the amenities these settings offer. The availability of land in floodprone areas, such as brownfields or former docklands, may drive expansion in these areas, as exemplified by New York City Mayor Bill de Blasio's decision to place more affordable housing along highly exposed shorelines (Bagley 2015). Given the market distortions introduced by government-subsidized flood insurance in high-income countries and the laissez-faire approaches to land management and growing informal settlements in low-income countries, we can expect that many more people - both the well off and the poor - will find themselves in flood zones in the future. While we may not have provided definitive evidence in this study of differential exposure in the two cities, we maintain that understanding the social protection needs of vulnerable populations will become increasingly important in the context of climate change (Johnson et al. 2013).

\section{References}

Abson, D. J., A. J. Dougill and L. C. Stringer 2012. Using principal component analysis for information-rich socio-ecological vulnerability mapping in Southern Africa. Applied Geography 35(1-2): 515-524.

Adger, N. 2003. Social capital, collective action, and adaptation to climate change. Economic Geography 79(4): 387-404.

Aerts J. C. J. H., N. Lin, W. Botzen, K. Emanuel and H. de Moel 2013. Low-probability flood risk modeling for new york city. Risk Analysis 33: 772-788

Agbola, T. and E. M. Agunbiade 2009. Urbanization, slum development and security of tenure: The challenges of meeting Millennium Development Goal 7 in Metropolitan Lagos, Nigeria". In Urban Population-Development-Environment Linkages in the Developing World, eds de Sherbinin et al. Paris: CICRED.

Al-rousan Tala, M., L. M. Rubenstein and R. B. Wallace 2014. Preparedness for natural disasters among older us adults: A nationwide survey. American Journal of Public Health 104(3): 506-511.

Aubrecht, C. and D. Özceylan 2013. Identification of heat risk patterns in the U.S. national capital region by integrating heat stress and related vulnerability. Environment International 56: 65-77.

Bagley, K. 2015. De Blasio Plans Affordable Housing in Areas Swamped by Hurricane Sandy. Inside Climate News, 4 February 2015. http://insideclimatenews.org/news/20150204/ de-blasio-plans-affordable-housing-areas-swamped-hurricane-sandy, accessed on 4 May 2015. 
Baud, I., N. Sridharan and K. Pfeffer 2008. Mapping urban poverty for local governance in an Indian mega-city: The case of Delhi. Urban Studies 45(7): 1385-1412.

Bazuin, J. T. and J. C. Frazier 2013. How the ACS gets it wrong: The story of the American Community Survey and a small, inner city neighborhood. Applied Geography 45: 292302.

Birkmann, J. 2011. Regulation and coupling of society and nature in the context of natural hazards. In Coping with Global Environmental Change, Disasters and Security, eds H. G. Brauch, U. Oswald Spring, C. Mesjasz, J. Grin, P. Kameri-Mbote, B. Chourou, P. Dunay and J. Birkmann, pp. 1103-1127. Springer, Berlin: Germany.

Bowen, W. M., M. J. Salling, K. E. Haynes and E. J. Cyran 1995. Toward environmental justice: Spatial equity in Ohio and Cleveland. Annals of the American Association of Geographers 84(4): 641-663.

Carreño M. L., O. D. Cardona and A. H. Barbat 2007. A disaster risk management performance index. Journal of Natural Hazards 41(1): 1-20.

Census of India 2011. Provisional population totals Paper 1 and 2. Available from: http://www.censusindia.gov.in/2011.

Confalonieri, U. E. C., D. P. Marinho and R. E. Rodriguez 2009. Public health vulnerability to climate change in Brazil. Climate Research 40: 175-186.

Crooks, D. 2009. Development and testing of the Elderly Social Vulnerability Index (ESVI): A composite indicator to measure social vulnerability in the Jamaican elderly population. Ph.D. Dissertation, Comparative Sociology. In FIU Electronic Theses and Dissertations. Paper 186. Florida International University.

Crowder, K. and L. Downey 2010. Interneighborhood migration, race, and environmental hazards: Modeling microlevel processes of environmental inequality. American Journal of Sociology 115(4).

Curtis, A., J. W. Mills and M. Leitner 2007. Katrina and vulnerability: The geography of stress. Journal of Health Care for the Poor and Underserved 18: 315-330.

Cutter S. L., B. J. Boruff, W. L. Shirley, et al. 2003. Social vulnerability to environmental hazards. Social Science Quarterly 84:242-261.

Cutter S. L. and C. T. Emrich 2006. The long road home: Race, class, and recovery from hurricane katrina. Environment: Science and Policy for Sustainable Development 48(2): $8-20$.

Cutter, S. L. and C. Corendea 2013. From social vulnerability to resilience: Measuring progress toward disaster risk reduction. SOURCE No. 17/2013. Bonn: United Nations University Institute for Environment and Human Security (UNU-EHS).

de Sherbinin, A., O. Wilhelmi and M. Hayden 2012. Exposure to heat stress in urban environments: Current Status and future prospects in a changing climate. Presentation at the Planet Under Pressure Conference, London UK, 26 March 2012.

de Sherbinin, A., A. Schiller and A. Pulsipher 2007. The vulnerability of global cities to climate Hazards. Environment and Urbanization 19(1): 39-64.

Demšar, U., P. Harris, C. Brunsdon, A. S. Fotheringham and S. McLoone 2013. Principal component analysis on spatial data: An overview. Annals of the Association of American Geographers 103(1): 106-128. 
Dhage, S. S., et al. 2006. Marine water quality assessment at Mumbai west coast. Environmental International 32: 149-158.

Emrich, C. 2011. The SoVI Recipe. University of South Carolina, Hazards and Vulnerability Research Institute, January 2011. http://webra.cas.sc.edu/hvri/docs/sovi_32_recipe.pdf, accessed on 20 June 2013.

Fekete, A. 2010. Social vulnerability to river floods in Germany. UNU-EHS Graduate Research Series, PhD Dissertation.

Fischer, E. M. and R. Knutti 2015. Anthropogenic contribution to global occurrence of heavy-precipitation and high-temperature extremes. Nature Climate Change, doi:10.1038/NCLIMATE2617.

Gibbs L.I. and C. S. Holloway, May 2013. Hurricane Sandy After Action Report and Recommendations to Mayor Michael R. Bloomberg, www.nyc.gov/html/recovery/ downloads/pdf/sandy_aar_5.2.13.pdf.

Goldstein, J. 2013. Death of Rockaways Man Is Linked to Hurricane Sandy. The New York Times. www.nytimes.com/2013/06/25/nyregion/ death-of-rockaways-man-is-linked-to-hurricane-sandy.html?_r=0, accessed on 24 June 2013.

Government of Maharashtra 2005. Maharashtra Floods 2005, Relief and Rehabilitation. http://mdmu.maharashtra.gov.in/pdf/Flood/statusreport.pdf.

Hallegatte, S., N. Ranger, F. Henriet, A. Patwardhan, K. Narayanan, S. Ghosh, et al. 2010. Flood Risks, Climate Change Impacts and Adaptation Benefits in Mumbai: An Initial Assessment of Socio-Economic Consequences of Present and Climate Change Induced Flood Risks and of Possible Adaptation Options. OECD Environment Working Papers, No. 27, Paris: OECD Publishing. http://dx.doi.org/10.1787/5km4hv6wb434-en.

Herring, S. C., M. P. Hoerling, T. C. Peterson and P. A. Stott 2014. Explaining extreme events of 2013 from a climate perspective. Special Supplement to the Bulletin of the American Meteorological Society 95(9).

Horton, R., C. Little, V. Gornitz, D. Bader and M. Oppenheimer 2015. New York City Panel on Climate Change 2015 Report Chapter 2: Sea Level Rise and Coastal Storms. Annals of the New York Academy of Sciences 1336: 36-44. doi:10.1111/nyas.12593.

Horton, R., C. Rosenzweig, V. Gornitz, D. Bader and M. O'Grady 2010. Climate risk information. Annals of the New York Academy of Sciences 1196(1): 147-228.

Houston, D., A. Werritty, D. Bassett, A. Geddes, A. Hoolachan and M. McMillan 2011. Pluvial (rain-related) flooding in urban areas: The invisible hazard. Joseph Rowntree Foundation, November 2011. http://www.jrf.org.uk.

Imhoff, M.L., P. Zhang, R.E. Wolfe and L. Bounoua 2010. Remote sensing of the urban heat island effect across biomes in the continental USA. Remote Sensing of Environment 114(3): 504-513.

IPCC (Intergovernemental Panel on Climate Change) 2012. Managing the Risks of Extreme Events and Disasters to Advance Climate Change Adaptation. In A Special Report of Working Groups I and II of the Intergovernmental Panel on Climate Change, eds A. Lavell, M. Oppenheimer, O.-D. Cardona, M. van Aalst, S. Seneviratne, N. Nicholls et al. Chapters 1, 2 and 3. Cambridge, UK, and New York, NY: Cambridge University Press. 
Intergovernemental Panel on Climate Change (IPCC) 2007. Climate Change 2007: The Physical Science Basis. In Contribution of Working Group I to the Fourth Assessment Report of the Intergovernmental Panel on Climate Change, eds S. Solomon, D. Qin, M. Manning, Z. Chen, M. Marquis, K. B. Averyt, M. Tignor and H. L. Miller, pp. 996. Cambridge, United Kingdom and New York, NY, USA: Cambridge University Press.

Jacob K. H., V. Gornitz and C. Rosenzweig 2007. Vulnerability of the New York City metropolitan area to coastal hazards, including sea-level rise: Inferences for urban coastal risk management and adaptation policies. In: Managing coastal vulnerability, eds L. McFadden, R. Nicholls and E. Penning-Rowsell. Oxford, UK: Elsevier Publishing.

Jha, A. K., R. Bloch and J. Lamon 2012. Cities and flooding. Washington, DC: The World Bank and GFDRR.

Johnson, C., H. B. Dulal, M. Prowse, K. Krishnamurthy and T. Mitchell 2013. Social protection and climate change: Emerging issues for research, policy and practice. Development Policy Review 31(s2): 2-18. doi:10.1111/dpr.12036.

Johnson, D. P. and J. S. Wilson 2009. The socio-spatial dynamics of extreme urban heat events: The case of heat-related deaths in Philadelphia. Applied Geography 29: 419-434.

Kinney, P. L., D. Shindell, E. Chae and B. Winston 2000. Climate change and public health: Impact assessment for the NYC Metropolitan Region. Metropolitan East Coast Climate Assessment. http://metroeast_climate.ciesin.columbia.edu/reports/health.pdf, accessed on 1 May 2015.

Kit, O., M. Lüdeke, D. Reckien 2011a. Texture-based identification of urban slums in Hyderabad, India using remote sensing data. Applied Geography 32: 660-667.

Kit, O., M. Lüdeke and D. Reckien 2011b. Assessment of climate change-induced vulnerability to floods in hyderabad, india, using remote sensing data. In Resilient cities: Cities and adaptation to climate change - Proceedings of the global forum 2010, local sustainability 1, ed. K. Otto-Zimmermann. Dortrecht, NL: Springer, Science+Business Media. doi:10.1007/978-94-007-0785-6_4

Kleinen, T. and G. Petschel-Held 2007. Integrated assessment of changes in flooding probabilities due to climate change. Climatic Change 81(3-4): 283-312.

Kumar, R., et al. 2008. Economic impact of climate change on Mumbai, India. WHO SEARO Regional Health Forum 12(1).

Lane, K., K. Charles-Guzman, K. Wheeler, Z. Abid, N. Graber and T. Matte 2013. Health effects of coastal storms and flooding in urban areas: A review and vulnerability assessment. Journal of environmental and public health 2013, Article ID 913064, 13 pages, http://dx.doi.org/10.1155/2013/913064.

Laska, S. 2006. Social vulnerabilities and hurricane Katrina: An unnatural disaster in New Orleans. Marine Technology Society 40(4): 1.

Lin, N., K. A. Emanuel, J. A. Smith and E. Vanmarcke 2010. Risk assessment of hurricane storm surge for New York City. Journal of Geophysical Research 115: D18121.

Maantay, J. and A. Maroko 2009. Mapping urban risk: Flood hazards, race, \& environmental justice in New York. Applied Geography 29: 111-124.

Madajewicz, M. and C. Coirolo 2015. Resilience to Climate Risks Evaluation. Presentation made at the Climate Change Research for the Urban Northeast Symposium, March 2015. 
Martine, G. and D. Schensul (eds) 2013. The demography of adaptation to climate change. New York, London, and Mexico City: UNFPA, IIED, and El Colegio de Mexico.

McDonald, R. I., P. Green, D. Balk, B.M. Fekete, C. Revenga, M. Todd and M. Montgomery 2011. Urban growth, climate change, and freshwater availability. Proceedings of the National Academy of Sciences. doi:10.1073/pnas.1011615108.

Mitchell, G. and D. Dorling 2003. An environmental justice analysis of British air quality. Environment and Planning A 35: 909-929.

Murthy, R.C., Y.R. Rao and A. Inamdar 2001. Integrated coastal management of Mumbai metropolitan region. Ocean E Coastal Management 44: 355-369.

Muttarak, R. and W. Pothisiri 2013. The role of education on disaster preparedness: Case study of 2012 Indian Ocean earthquakes on Thailand's Andaman coast. Ecology $\mathcal{E}$ Society 18(4): 51.

Nicholls, R. J., S. Hanson, C. Herweijer, N. Patmore, S. Hallegatte, J. Corfee-Morlot, J. Chateau and R. Muir-Wood 2008. Ranking port cities with high exposure and vulnerability to climate extremes: Exposure estimates. OECD Environment Working Papers, No. 1, OECD Publishing.

Nyakaana, J. B. 2006. Population, Urban Development and the Environment in Uganda: The Case of Kampala City and its Environs. PRIPODE Project Final Report.

O'Brien, K., S. Eriksen, L. P. Nygaard and A. N. E. Schjolden 2007. Why different interpretations of vulnerability matter in climate change discourses. Climate Policy 7(1): 73-88.

Parry, M. L., O. F. Canziani, J. P. Palutikof, et al. 2007. Impacts, adaptation and vulnerability. In Contribution of Working Group II to the Fourth Assessment Report of the Intergovernmental Panel on Climate Change, eds M. L. Parry, O. F. Canziani, J. P. Palutikof, P. J. van der Linden and C. E. Hanson. Cambridge, UK: Cambridge University Press.

Parthasarathy, D. 2009. Social and environmental insecurities in Mumbai: Towards a sociological perspective on vulnerability. South African Review of Sociology 40(1).

Pelling, M. 2002. Assessing urban vulnerability and social adaptation to risk: Evidence from Santo Domingo. IDPR 24(1): 59-76.

Prasad N., Ranghieri F., Shah F., Trohanis Z., Kessler E. and Sinha R. 2009. Climate resilient cities - A primer on reducing vulnerabilities to disasters. Washington, DC: The World Bank.

Preston, B. L., D. Abbs, B. Beveridge, C. Brooke, R. Goddard, G. Hunt, M. Justus, P. Kinrade, I. Macadam, T. G. Measham, K. McInnes, C. Morrison, J. O’Grady, T. F. Smith and G. Withycombe 2007. Spatial Approaches for Assessing Vulnerability and Consequences in Climate Change Assessments. In Proceedings of MODSIM 2007: International Congress on Modelling and Simulation. Christchurch, NZ: Modelling and Simulation Society of Australia and New Zealand.

Ranger, N., S. Hallegatte, S. Bhattacharya M. Machu, S. Priya, K. Dhore, et al. 2011. An assessment of the potential impact of climate change on flood risk in Mumbai. Climatic Change 104: 139-167.

Reckien, D., S. Lwasa, et al. forthcoming. Climate interactions with equity and environmental justice. In: Climate change and cities: Second assessment report of the Urban Climate 
Change Research Network, eds Rosenzweig et al. Cambridge UK: Cambridge University Press.

Reckien, D., M. Wildenberg and M. Bachhofer 2013. Subjective realities of climate change: How mental maps of impacts deliver socially sensible adaptation options. Sustainability Science 8: 159-172.

Romero-Lankao, P., H. Qin and M. Borbor-Cordova 2013. Exploration of health risks related to air pollution and temperature in three Latin American cities. Social Science and Medicine 83: 110-118.

Romero-Lankao, P. and H. Qin 2010. Conceptualizing urban vulnerability to global climate and environmental change. Current Opinion in Environmental Sustainability 3(3): 142-149.

Rosenzweig, C., W. D. Solecki, S. A. Hammer and S. Mehrotra (eds) 2011a. Climate change and cities: First assessment report of the Urban Climate Change Research Network. Cambridge: Cambridge University Press.

Rosenzweig, C., W. D. Solecki, R. Blake, M. Bowman, C. Faris, V. Gornitz, R. Horton, K. Jacob, A. LeBlanc, R. Leichenko, M. Linkin, D. Major, M. O’Grady, L. Patrick, E. Sussman, G. Yohe and R. Zimmerman 2011b. Developing coastal adaptation to climate change in the New York City infrastructure-shed: Process, approach, tools, and strategies. Climatic Change 106: 93-127.

Rosenzweig, C. and W. Solecki 2010. Climate change adaptation in New York City. Annals of the NY Academy of Science 1196.

Rygel, L., D. O’Sullivan and B. Yarnal 2006. A method for constructing a social vulnerability index: An application to hurricane storm surges in a developed country. Mitigation and Adaptation Strategies for Global Change 11: 741-764.

Schmidtlein M. C., R. C. Deutsch, W. W. Piegorsch and S. L. Cutter 2008. A sensitivity analysis of the social vulnerability index. Risk Analysis 28: 1099-1114.

Sliuzas, R., V. Jetten, J. Flacke, S. Lwasa, J. Wasige and G. Pettersen 2013. Flood risk assessment, strategies and actions for improving flood risk management in Kampala. Report of the Integrated Flood Management Kampala project under Habitat's Cities and Climate Change Initiative. Nairobi, Kenya: UN-HABITAT.

Sliuzas, R., G. Mboup and A. de Sheribnin 2008. Report on Expert Group Meeting on Slum Identification and Mapping 21-23 May 2008, Enschede, Netherlands: Organized by CIESIN, ITC, and UNHABITAT.

Soares, M. B., A. S. Gagnon and R. M. Doherty 2012. Conceptual elements of climate change vulnerability assessments. International Journal of Climate Change Strategies and Management 4(1): 6-35.

Spielman, S. E., D. Folch, N. Nagle 2014. Patterns and causes of uncertainty in the American community survey. Applied Geography 46: 147-157.

Storch, H., N. Downes and H. Rujner 2011. A scenario-based approach to assessing the exposure and flood risk of Ho Chi Minh City's urban development strategy in times of climate change. In EnviroInfo 2011: Innovations in sharing - Environmental observations and information, eds W. Pillmann, S. Schade and P. Smits. Ispra, Italy: Shaker Verlag.

The New York Times, 17/11/2012, Hurricane Sandy's Deadly Toll. www.nytimes.com/2012/ 11/18/nyregion/hurricane-sandys-deadly-toll.html?pagewanted=all. 
The Times of India, Nakaskar R., 20/07/2011, Mumbai, a land of opportunities. http://articles.timesofindia.indiatimes.com/2011-07-20/mumbai/29793908_1_ south-mumbai-mumbai-houses-bfsi.

Thornton, P. K., P. G. Jones, T. Owiyo, R. L. Kruska, et al. 2008. Climate change and poverty in Africa: Mapping hotspots of vulnerability. AfJARE 2(1): March 2008.

Uejio, C. K., O. V. Wilhelmi, J. S. Golden, D. M. Mills, S. P. Gulino and J. P. Samenow 2011. Intra-urban societal vulnerability to extreme heat: The role of heat exposure and the built environment, socioeconomics, and neighborhood stability. Health and Place 17: 498-507.

UNFPA (United Nations Population Fund) 2007. 2007 State of the world population: Unleashing the potential of urban growth. New York: UNFPA.

USC (University of South Carolina), Hazards and Vulnerability Research Institute. Undated. Changes and Improvements in the SoVI ${ }^{\circledR}$ Formulation for 2006-10. Accessed on 20 June 2013 at http://webra.cas.sc.edu/hvri/products/sovi_details_2006.aspx.

Weber, S., N. Sadoff, E. Zell and A. de Sherbinin 2015. Policy-relevant indicators for mapping the vulnerability of urban populations to extreme heat events: A case study of philadelphia. Applied Geography 63: 231-243. http://dx.doi.org/10.1016/j.apgeog.2015.07.006.

Welle, T., Y. Depietri, M. Angignard, J. Birkmann, F. Renaud and S. Greiving 2014. Vulnerability assessment to heat waves, floods, and earthquakes Using the MOVE framework: Test case Cologne, Germany. In Assessment of vulnerability to natural hazards, eds J. Birkmann, S. Kienberger and D. Alexander, Chapter 5. Amsterdam: Elsevier.

WHO (World Health Organization) 2010. Environment and health risks: A review of the influence and effects of social inequalities. Copenhagen: WHO Regional Office for Europe. http://www.euro.who.int/_data/assets/pdf_file/0003/78069/E93670.pdf, accessed on 4 November 2014.

Wilhelmi, O. V., K. L. Purvis and R. C. Harriss 2004. Designing a geospatial information infrastructure for the mitigation of heat wave hazards in urban areas. Natural Hazards Review 5(3): 147-158.

Winsemius, H. C., B. Jongman, T. I. E. Veldkamp, S. Hallegatte, M. Bangalore and P. J. Ward 2015. Disaster risk, climate change, and poverty: Assessing the global exposure of poor people to floods and droughts. World Bank Policy Research Working Paper WPS7480. Washington DC: World Bank.

\section{Appendix: Correlation and covariance matrices}

Correlation and covariance matrices are on the following pages. 


\begin{tabular}{|c|c|c|c|c|c|c|c|c|c|c|c|c|c|c|c|c|c|c|c|c|}
\hline 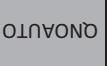 & \& & 亭 & ti & 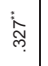 & 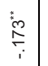 & 党 & 亦 & 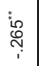 & 萬 & ్ֶ & $\bar{\square}$ & 寺 & 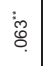 & 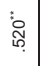 & $\stackrel{8}{\circ}$ & हे & : ه్ & 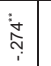 & 童 & - \\
\hline 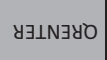 & : & 每 & : & 点 & 离 & . & . & 菊 & 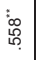 & 范 & 萬 & 雍 & i̊. & 它 & $\stackrel{8}{\circ}$ & 苔 & . & \%) & $\begin{array}{lll}- & \\
\end{array}$ & 点 \\
\hline LINกdd & 英 & 总 & $\stackrel{5}{E}$ & ¿్ర & 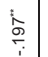 & . & 察 & | & 象 & : & 年 & 常 & 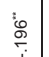 & 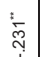 & is & 察 & to & 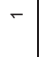 & og. & $\stackrel{\text { a }}{4}$ \\
\hline SN $\exists O d O d$ & ה̃ & 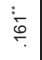 & io & : & $\begin{array}{l}\vdots \\
\vdots \\
\vdots \\
i\end{array}$ & 年 & 望 & 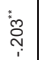 & مִ & : & 势 & 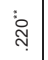 & : & 品 & 然 & ?: & - & $\stackrel{\text { fo }}{c}$ & 要 & \%ั \\
\hline ธэาгтаэ๐ & m. & 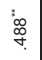 & ֶֻ. & స్రి & 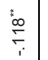 & 离 & : & $\stackrel{0}{0}$ & 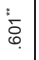 & 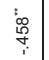 & 每 & $\stackrel{\hbar}{6}$ & : & 余 & 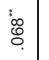 & - & ?: & 安 & 官 & हे \\
\hline SЭYYYNO & $\stackrel{m}{\circ}$ & (ס) & 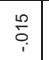 & 芯 & 安 & 음 & : & 范 & 落 & 文 & z & $\stackrel{\infty}{5}$ & s. & $\stackrel{8}{8}$ & - & 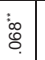 & 总 & 年 & $\stackrel{8}{\circ}$ & $\stackrel{8}{\circ}$ \\
\hline $\mathrm{HH} \mathrm{HO}^{-}$ & 尊 & : & 童 & ָָ & ơ & : & $\bar{t}_{0}$ & 总 & 亩 & 定 & : స్ & 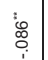 & : & 厂 & $\stackrel{0}{0}$ & 氙 & i & 啇 & 要 & . ְิ \\
\hline$\exists 7 \forall W= \pm 0$ & 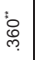 & 然 & ڤั̀ & 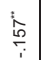 & 定 & ఫ్లి & 惫 & 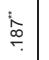 & $\bar{\Xi}$ & $\stackrel{n}{0}$ & s. & 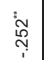 & - & (ס) & s. & : & \% & 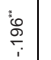 & ڤ్రి & 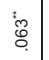 \\
\hline $75 \exists 0$ & 䒴 & 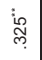 & : & 它 & 豙 & : & : & : & s. & 市 & 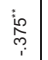 & - & ָָָ & 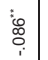 & $\stackrel{m}{c}$ & 它 & สั่ & 吊 & 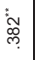 & 辛 \\
\hline d $\forall \supset y \exists d$ & 要 & ్ָָ & $\stackrel{\circ}{\circ}$ & $\frac{1}{4}$ & : & 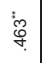 & 范 & ֶֶ: & 它 & 密 & - & 年 & sis & : & 定 & 葛 & f & | & 离 & $\bar{\circ}$ \\
\hline 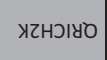 & 家 & 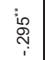 & 誉 & 要 & : & 点 & 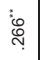 & 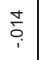 & 宫 & - & 柋 & 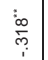 & ơ & 党 & 市. & 年 & . & 。 & 范 & 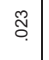 \\
\hline$\Lambda \perp \wedge$ OdO & ণิ่ & 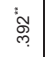 & 家 & 字 & 年 & 草 & p. & 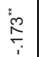 & r & 总 & 要 & 誉 & $\overline{\check{\sigma}}$ & 离 & 岁 & t. & 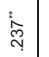 & 等 & 列 & 岁 \\
\hline $\mathrm{N} 3 \mathrm{gSSO}$ & $\stackrel{0}{0}$ & 每 & $\stackrel{\infty}{\circ}$ & 䓦 & 离 & : & 年 & - & ?ִ & . & $\stackrel{0}{0}$ & $\begin{array}{l}0 \\
:\end{array}$ & 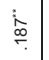 & 党 & tho & 号 & مִ & : & 荀 & هִ \\
\hline эอУवэW & 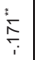 & 它 & . & 年 & 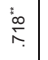 & 要 & - & 字 & 镑 & : & 菺 & : & 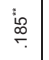 & : & "্ণ & 尽 & : & 变 & 总 & 冓 \\
\hline$w \forall נ 0$ & है & זֶׁ & צ̧ & 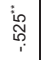 & : & - & io & : & 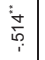 & 容 & 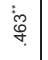 & 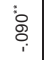 & ळ్లి & 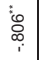 & $\stackrel{0}{\circ}$ & 艿 & 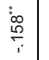 & 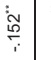 & 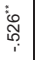 & 苨 \\
\hline $\mathrm{d} \exists \triangle \exists \ni \vee 0$ & רָ & דֶ. & 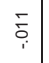 & 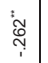 & - & : & 鼠 & 豙 & 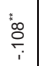 & 范 & . & 密 & 商 & 察 & s. & $\stackrel{\infty}{\stackrel{\infty}{\circ}}$ & : & 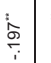 & 离 & ? \\
\hline dSIHO & స్ & 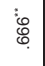 & 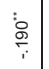 & - & :ֶّ & 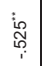 & : & 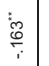 & 官 & 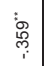 & 字 & $\frac{1}{\circ}$ & th & ָָ & d્t & 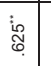 & (") & ¿ू్ర & 竞 & స్ల \\
\hline NVISVO & 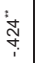 & 莡 & - & 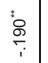 & 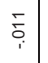 & צֶ. & مָ & $\stackrel{\infty}{\circ}$ & : & $\stackrel{\infty}{0}_{0}^{0}$ & $\stackrel{0}{0}$ & "ृ. & ڤั̀ & 年 & 号 & סّ̊ & to & : & : & 要 \\
\hline W $\forall \perp \forall N O$ & 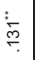 & - & مَ & : & : & 蓙 & 它 & 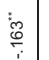 & 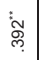 & : & 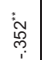 & ¿્ల & : & 臱 & 然 & 象 & 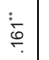 & 总 & : & 客 \\
\hline ХरУ & - & $\frac{-}{m}$ & đ̧ & ָָ̧ & 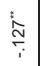 & 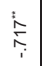 & 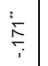 & 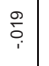 & :ָे & 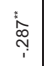 & (ס) & 䒴 & 苂 & 尊 & $\stackrel{\infty}{5}$ & סू & : & 驾 & $\stackrel{*}{\stackrel{2}{c}}$ & to \\
\hline & 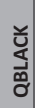 & $\begin{array}{l}\sum \\
k \\
5 \\
2 \\
2\end{array}$ & $\left|\begin{array}{l}z \\
\frac{z}{w} \\
\frac{a}{\delta}\end{array}\right|$ & $\frac{\hat{\frac{\hat{T}}{\sigma}}}{\bar{\sigma}}$ & 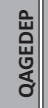 & 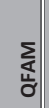 & 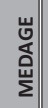 & $\begin{array}{l}z \\
\text { zụ̂ } \\
\text { ơ }\end{array}$ & $\begin{array}{l}\vec{z} \\
0 \\
o \\
o\end{array}$ & 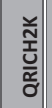 & 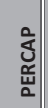 & 岕 & 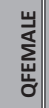 & $\begin{array}{l}\frac{T}{\underline{T}} \\
\text { 音 }\end{array}$ & 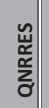 & 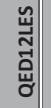 & 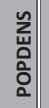 & \begin{tabular}{l||}
$\frac{t}{2}$ \\
$\frac{1}{a}$ \\
\end{tabular} & 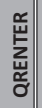 & 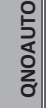 \\
\hline
\end{tabular}




\begin{tabular}{|c|c|c|c|c|c|c|c|c|c|c|c|c|c|c|c|c|c|c|c|c|c|}
\hline & OINZONO & 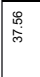 & $\stackrel{\bar{g}}{\dot{\sigma}}$ & $\begin{array}{l}\infty \\
\bar{\varphi} \\
\bar{\varphi}\end{array}$ & 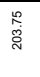 & $\begin{array}{l}\text { ָू } \\
\text { ָे }\end{array}$ & 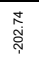 & 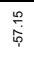 & 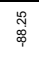 & $\begin{array}{l}\text { 志 } \\
\stackrel{\alpha}{\sigma}\end{array}$ & 趸 & $\begin{array}{l}\overline{\bar{o}} \\
\overline{0} \\
\bar{o} \\
\bar{c}\end{array}$ & 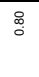 & 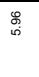 & $\begin{array}{l}\text { 邑 } \\
\stackrel{0}{0} \\
\stackrel{0}{0}\end{array}$ & চ̄ & 志 & 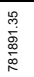 & 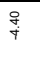 & & ৫̊: \\
\hline & YIIN 3 YO & $\begin{array}{l}\widehat{\infty} \\
\text { 心్ }\end{array}$ & $\stackrel{\infty}{\stackrel{\circ}{\sim}}$ & 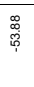 & $\begin{array}{l}\text { g. } \\
\stackrel{్}{2}\end{array}$ & 苗 & 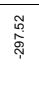 & $\underset{\text { j. }}{\bar{j}}$ & 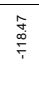 & $\begin{array}{l}\mathcal{F} \\
\text { 品 } \\
\text { 作 }\end{array}$ & 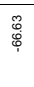 & 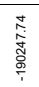 & $\stackrel{\widehat{N}}{=}$ & 哭 & $\begin{array}{l}\text { Fै } \\
\text { ळ. }\end{array}$ & ¿্口 & 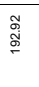 & 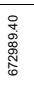 & $\begin{array}{l}\text { ơ } \\
\text { ô }\end{array}$ & & 胥 \\
\hline & LINndd & 党 & $\stackrel{\hat{0}}{0}$ & 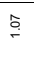 & 第 & $\begin{array}{l}\bar{\Phi} \\
\stackrel{\phi}{\phi}\end{array}$ & 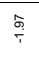 & $\stackrel{8}{7}$ & 品 & $\stackrel{\text { g }}{\mathrm{N}}$ & ్ָ & $\begin{array}{l}\text { 怘 } \\
\text { \%ू }\end{array}$ & 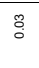 & 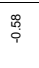 & $\underset{\tilde{\sigma}}{\leftarrow}$ & 8 & 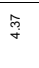 & 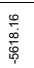 & 今. & & $\underset{q}{q}$ \\
\hline & SNGOdOd & 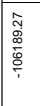 & 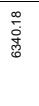 & 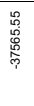 & 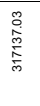 & 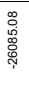 & 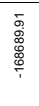 & 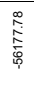 & 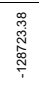 & 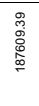 & 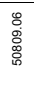 & 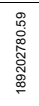 & 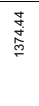 & 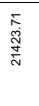 & $\begin{array}{l}\bar{c} \\
\infty \\
\tilde{D} \\
\bar{\sigma} \\
\end{array}$ & 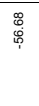 & 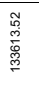 & 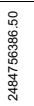 & 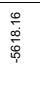 & & 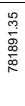 \\
\hline & SэาZโ0э0 & 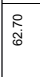 & 总 & $\stackrel{\circ}{\circ}$ & $\begin{array}{l}\text { 尺̃ } \\
\text { N్ }\end{array}$ & : & $\begin{array}{l}\bar{m} \\
\stackrel{0}{0} \\
\stackrel{0}{\varphi}\end{array}$ & $\begin{array}{l}\text { 品 } \\
\text { o. } \\
\text { p. }\end{array}$ & 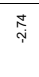 & $\begin{array}{l}\stackrel{8}{0} \\
\stackrel{\phi o g}{+}\end{array}$ & 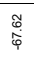 & $\begin{array}{l}\text {. } \\
\text { 总 } \\
\text { 惫 }\end{array}$ & 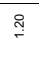 & 骂 & 号 & 苂 & 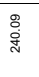 & 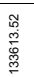 & 娐 & & 志 \\
\hline & SJyYNo & ¿̄ & $\stackrel{8}{\circ}$ & 产 & ơ & $\stackrel{8}{8}$ & ¿. & $\stackrel{\leftrightarrow}{0}$ & 今̊ & õ & 产 & 芯 & $\stackrel{8}{\circ}$ & ¿̄o & ¿̄ & $\stackrel{8}{8}$ & 䓵 & 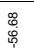 & $: 8$ & 衣 & 产 \\
\hline & $\mathrm{HH}=\mathrm{O}$ & 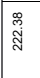 & స్ & 怘 & $\begin{array}{l}\text { 惫 } \\
\text { 邑 }\end{array}$ & $\frac{\pi}{\dot{T}}$ & 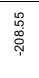 & 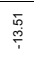 & : & 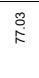 & 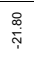 & 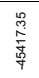 & بั & : & 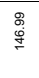 & $\bar{\circ}$ & 总 & 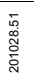 & $\stackrel{\tilde{\sigma}}{\leftarrow}$ & & 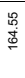 \\
\hline & 37४WजษO & 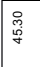 & స̃ & $\begin{array}{l}\infty \\
\stackrel{\infty}{i} \\
\stackrel{m}{i}\end{array}$ & 苋 & $\stackrel{\overbrace{}}{\sim}$ & $\begin{array}{l}\text { 古 } \\
\text { ه̦ }\end{array}$ & 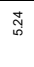 & 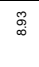 & $\stackrel{\Xi}{\leftarrow}$ & $\stackrel{0}{i}$ & 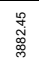 & $\stackrel{m}{i}$ & $\stackrel{\text { ă }}{\underset{\sim}{N}}$ & $\begin{array}{l}\text { M. } \\
\stackrel{d}{d}\end{array}$ & $\bar{o}_{0}$ & 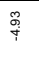 & 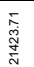 & 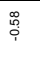 & & 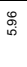 \\
\hline & 7530 & $\stackrel{\bar{T}}{\bar{T}}$ & $\stackrel{0}{\circ}$ & 尺̃ & 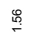 & 苂 & 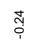 & $\overbrace{i}^{ \pm}$ & $\stackrel{m}{\dot{c}}$ & : & 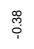 & $\begin{array}{l}\overline{\tilde{g}} \\
\tilde{\widetilde{d}}\end{array}$ & $\stackrel{\widetilde{0}}{0}$ & $\stackrel{m}{i}$ & $\stackrel{ \pm}{ \pm}$ & $:$ & $\stackrel{\text { ণิ }}{\longrightarrow}$ & $\begin{array}{c}\text { 売 } \\
\text { 总 }\end{array}$ & $\stackrel{\text { : }}{\circ}$ & $\stackrel{\widehat{N}}{\leftrightarrows}$ & $\begin{array}{c}\infty \\
0 \\
0\end{array}$ \\
\hline & $d \forall \supset y \exists d$ & 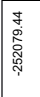 & 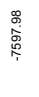 & 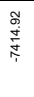 & 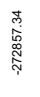 & 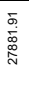 & 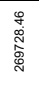 & $\begin{array}{l}\text { \% } \\
0 \\
\stackrel{0}{0} \\
0\end{array}$ & $\begin{array}{l}\text { 果 } \\
\text { d }\end{array}$ & 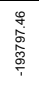 & $\begin{array}{l}\text { ज̃ } \\
\text { ָิ్ } \\
\text {. }\end{array}$ & 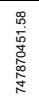 & $\begin{array}{l}\bar{c} \\
\stackrel{\text { onj }}{\dddot{i}}\end{array}$ & 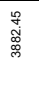 & 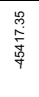 & 志 & 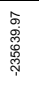 & 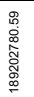 & 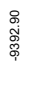 & & 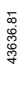 \\
\hline & 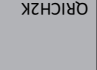 & 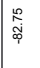 & $\overline{\text { ָे }}$ & $\stackrel{\infty}{\stackrel{\circ}{\leftarrow}}$ & $\underset{\substack{\underline{\underline{p}} \\
\bar{\phi}}}{ }$ & 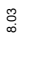 & $\begin{array}{l}\mathscr{8} \\
\infty \\
\infty\end{array}$ & $\stackrel{\stackrel{\mathscr{p}}{\sim}}{\stackrel{\sim}{\sim}}$ & $\stackrel{\mathscr{B}}{\stackrel{\leftrightarrow}{\leftarrow}}$ & $\begin{array}{l}\stackrel{8}{\mathrm{G}} \\
\stackrel{్}{\rho}\end{array}$ & $\begin{array}{l}\circ \\
\stackrel{\leftrightarrow}{\circ}\end{array}$ & $\begin{array}{l}\text { ָ̃ } \\
\text { స్ํ }\end{array}$ & 足 & $\stackrel{\circ}{0}$ & $\begin{array}{l}\stackrel{\infty}{+} \\
\stackrel{i}{+}\end{array}$ & 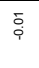 & 葛 & $\begin{array}{l}\text { : } \\
\text { o. } \\
\text { o. } \\
0\end{array}$ & $\overline{\text { ָे }}$ & & 奋 \\
\hline & AINOdO & $\begin{array}{l}\text { 壳 } \\
\dot{S}\end{array}$ & 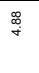 & 志 & $\begin{array}{l}\stackrel{\infty}{\infty} \\
\stackrel{\infty}{\sim}\end{array}$ & 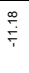 & $\begin{array}{l}\stackrel{\infty}{N} \\
\end{array}$ & 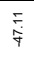 & $\begin{array}{l}\text { qu } \\
\text { va }\end{array}$ & $\begin{array}{l}\hat{a} \\
\text { dod } \\
\text { de }\end{array}$ & 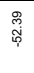 & 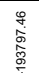 & $\stackrel{\infty}{\circ}$ & $\stackrel{\infty}{-}$ & 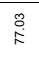 & ¿̊. & 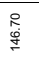 & $\begin{array}{l}\text { o. } \\
0 \\
0 \\
0 \\
0 \\
0\end{array}$ & $\stackrel{\text { g }}{\text { J }}$ & & 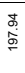 \\
\hline & $\mathrm{N} 3 \mathrm{gSSO}$ & $\stackrel{8}{9}$ & $\stackrel{\bar{\sigma}}{\stackrel{i}{*}}$ & ণ̃ & 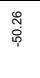 & N̂̀ & 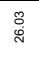 & $\begin{array}{l}\bar{\lambda} \\
\text { o }\end{array}$ & 荀 & 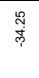 & $\stackrel{\mathscr{\leftrightarrow}}{\rightarrow}$ & 产 & $\stackrel{m}{i}$ & $\underset{\substack{\mathscr{\infty} \\
\infty \\
\infty}}{ }$ & $\stackrel{\mathscr{ׁ}}{i}$ & $\stackrel{\widetilde{0}}{0}$ & 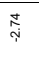 & 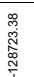 & 品 & & 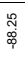 \\
\hline & उอУवヨW & 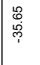 & $\stackrel{\infty}{\leftarrow}$ & $\begin{array}{l}\stackrel{\widetilde{\sigma}}{\circ} \\
\stackrel{\sigma}{\sigma}\end{array}$ & 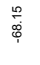 & 总 & $\stackrel{\circ}{\circ}$ & 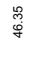 & $\begin{array}{l}\bar{N} \\
\text { g }\end{array}$ & 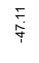 & 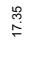 & $\begin{array}{l}\text { ஃ } \\
\text { : } \\
\text { : }\end{array}$ & $\stackrel{+}{+}$ & 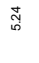 & $\begin{array}{l}\bar{c} \\
\stackrel{p}{i}\end{array}$ & $\stackrel{8}{\circ}$ & 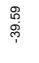 & 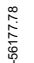 & $\stackrel{8}{\div}$ & & 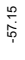 \\
\hline & WVAO & 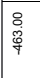 & $\stackrel{\substack{T \\
T}}{T}$ & $\begin{array}{l}\stackrel{\mathscr{L}}{ } \\
\stackrel{\widetilde{q}}{+}\end{array}$ & 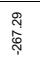 & $\begin{array}{l}\vec{D} \\
\text { d. }\end{array}$ & $\begin{array}{l}\text { 喿 } \\
\text { 守 }\end{array}$ & $\stackrel{9}{\stackrel{9}{0}}$ & 常 & & 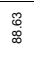 & 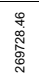 & 壱 & 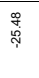 & 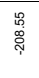 & Б。. & 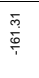 & 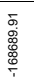 & $\stackrel{\hat{\sigma}}{\bar{\tau}}$ & & $\begin{array}{l}\text { ते } \\
\text { ָे }\end{array}$ \\
\hline & d]Oتgvo & 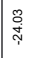 & ণิ & & 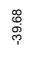 & 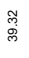 & $\begin{array}{l}\text { ‡. } \\
\text { o } \\
\text { p. }\end{array}$ & $\begin{array}{l}\text { o } \\
\text { o } \\
\text { p. }\end{array}$ & $\hat{\grave{g}}$ & $\stackrel{\infty}{\square}$ & $\stackrel{\infty}{\infty}$ & $\begin{array}{l}\bar{\sigma} \\
\bar{\sigma} \\
\bar{\alpha} \\
\Sigma\end{array}$ & 菅 & $\stackrel{\text { I }}{\sim}$ & $\frac{N}{\dot{y}}$ & $\stackrel{8}{\circ}$ & 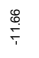 & $\begin{array}{l}\infty \\
0 \\
0 \\
0 \\
0\end{array}$ & 啇 & & $\begin{array}{l}\text { N్ } \\
\text { ָे }\end{array}$ \\
\hline$\stackrel{\vec{E}}{\pi}$ & dSIHO & 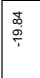 & 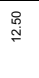 & 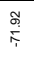 & 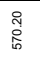 & ఊ্口ে & 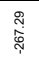 & $\begin{array}{l}\stackrel{0}{0} \\
\substack{\phi \\
\varphi}\end{array}$ & 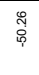 & 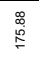 & $\frac{\bar{\omega}}{\bar{\phi}}$ & 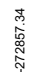 & 足 & $\begin{array}{l}\text { 范 } \\
\text { 守 }\end{array}$ & 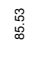 & ¿̊ & $\begin{array}{l}\tilde{\tilde{\nu}} \\
\tilde{\tilde{N}}\end{array}$ & 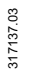 & 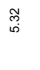 & \begin{tabular}{l} 
g. \\
\multirow{N}{*}{}
\end{tabular} & 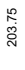 \\
\hline$\underset{\Xi}{ }$ & NVISVO & 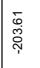 & $\stackrel{\mathscr{8}}{-}$ & 察 & 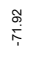 & & $\begin{array}{l}\stackrel{\mathscr{N}}{\tilde{g}} \\
\stackrel{\sim}{\sim}\end{array}$ & $\begin{array}{l}\text { Oे } \\
\stackrel{\sigma}{\sigma}\end{array}$ & స̃ & 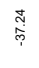 & $\stackrel{\infty}{\stackrel{\infty}{\leftarrow}}$ & 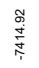 & م્ & 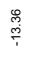 & 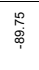 & $\bar{o}_{i}$ & $\stackrel{8}{\circ}$ & $\begin{array}{l}0 \\
0 \\
0.0 \\
0.0 \\
0.0 \\
0.0\end{array}$ & $\stackrel{a}{\stackrel{5}{r}}$ & & $\begin{array}{l}\mathscr{\infty} \\
\stackrel{\square}{\bar{\varphi}}\end{array}$ \\
\hline హె & WVIVNO & $\stackrel{N}{\infty}$ & $\bar{\delta}$ & $\stackrel{\mathscr{\infty}}{\leftarrow}$ & $\stackrel{\stackrel{\leftrightarrow}{\sim}}{\sim}$ & $\stackrel{\text { Tิ }}{\longrightarrow}$ & 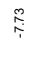 & $\stackrel{\infty}{\leftarrow}$ & $\stackrel{\bar{\varphi}}{\longrightarrow}$ & 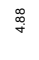 & $\overline{\grave{y}}$ & 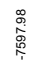 & $\stackrel{ొ 0}{\circ}$ & స̂̀ & $\overline{\tilde{N}}$ & : & 怘 & $\begin{array}{l}\frac{\infty}{0} \\
\text { 嚆 }\end{array}$ & $\hat{\mathrm{t}}$ & 怘 & $\underset{\dot{\sigma}}{\dot{q}}$ \\
\hline$\underset{0}{0}$ & 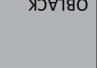 & $\begin{array}{l}\overline{\bar{\sigma}} \\
\stackrel{5}{\sigma}\end{array}$ & $\stackrel{\sim}{\stackrel{\sim}{p}}$ & $\begin{array}{l}\bar{c} \\
\text { d़े }\end{array}$ & $\begin{array}{l}\text { 志 } \\
\stackrel{\sigma}{T}\end{array}$ & 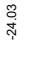 & 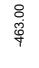 & 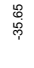 & $\stackrel{\substack{0 \\
:}}{0}$ & $\begin{array}{l}\stackrel{t}{\circ} \\
\&\end{array}$ & 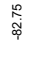 & $\begin{array}{l}\text { Ja } \\
\text { o. } \\
\text { W. } \\
\text { N }\end{array}$ & & $\begin{array}{l}\stackrel{0}{0} \\
\dot{g} \\
\dot{g}\end{array}$ & $\begin{array}{l}\infty \\
\stackrel{\sim}{\mathbb{N}} \\
\end{array}$ & Бे & 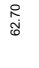 & $\begin{array}{l}\bar{y} \\
\mathbb{\infty} \\
\overline{0} \\
\overline{0}\end{array}$ & $\stackrel{\text { S }}{\sim}$ & & 总 \\
\hline$\frac{0}{2}$ & 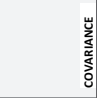 & $\mid \begin{array}{l}\mathrm{z} \\
\mathbf{s} \\
\text { ơ }\end{array}$ & 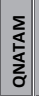 & $\begin{array}{l}z \\
\frac{\alpha}{u} \\
\text { dे }\end{array}$ & $\begin{array}{l}\frac{\hat{v}}{\bar{T}} \\
\frac{1}{\sigma}\end{array}$ & 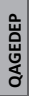 & 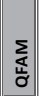 & 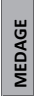 & $\begin{array}{l}z \\
\text { z } \\
\text { o } \\
\text { d }\end{array}$ & $\begin{array}{l}\overrightarrow{5} \\
0 \\
o \\
o\end{array}$ & $\begin{array}{l}\frac{\mathrm{v}}{\mathrm{T}} \\
\frac{\mathrm{U}}{\tilde{\sigma}}\end{array}$ & 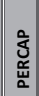 & $\overrightarrow{\underline{d}}$ & 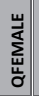 & 章 & 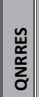 & 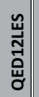 & $\begin{array}{l}\sum_{\mathrm{U}} \\
\mathrm{a} \\
\text { 응 }\end{array}$ & $\begin{array}{l}\mathbf{b} \\
\frac{\mathbf{b}}{2}\end{array}$ & 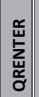 & 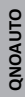 \\
\hline
\end{tabular}




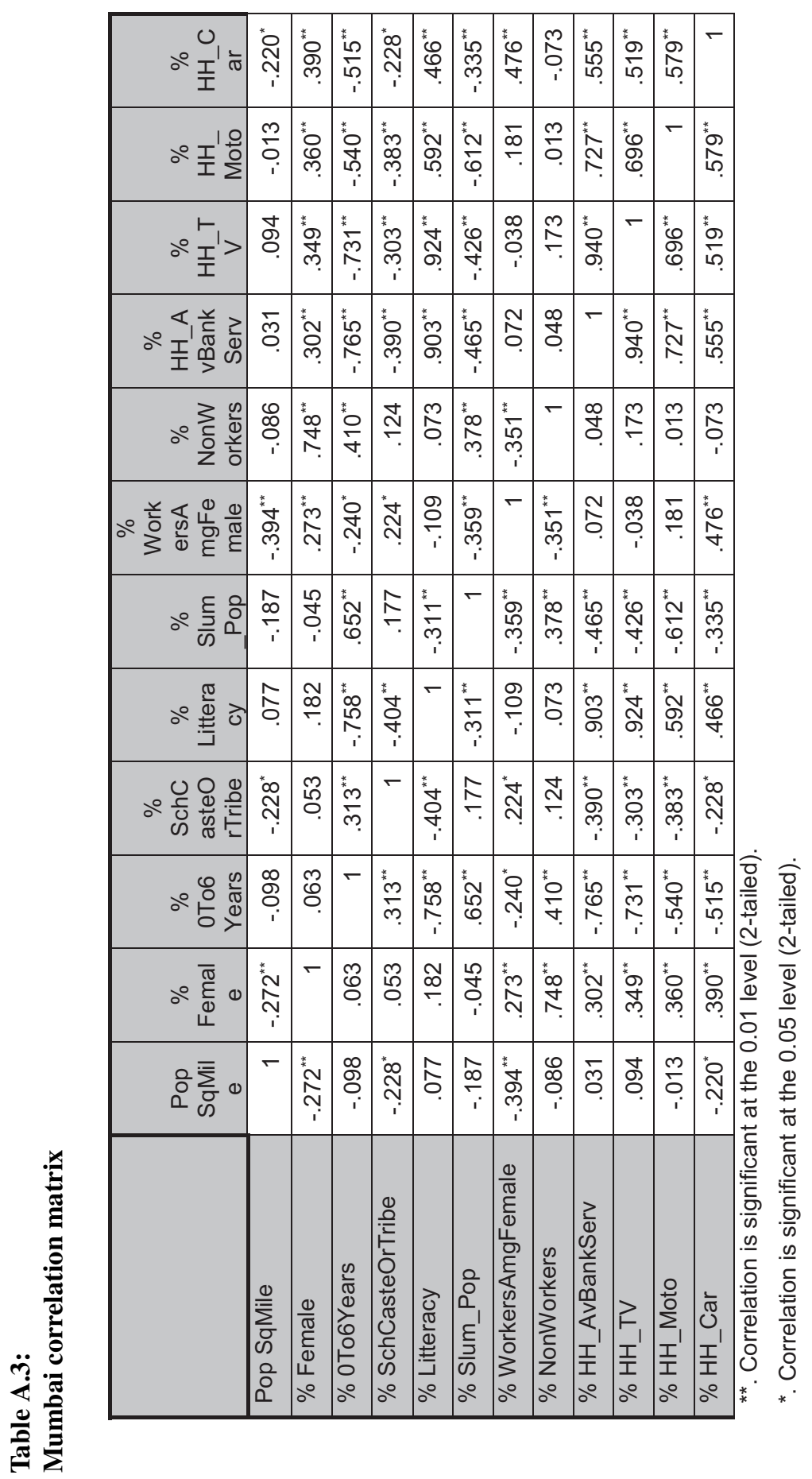




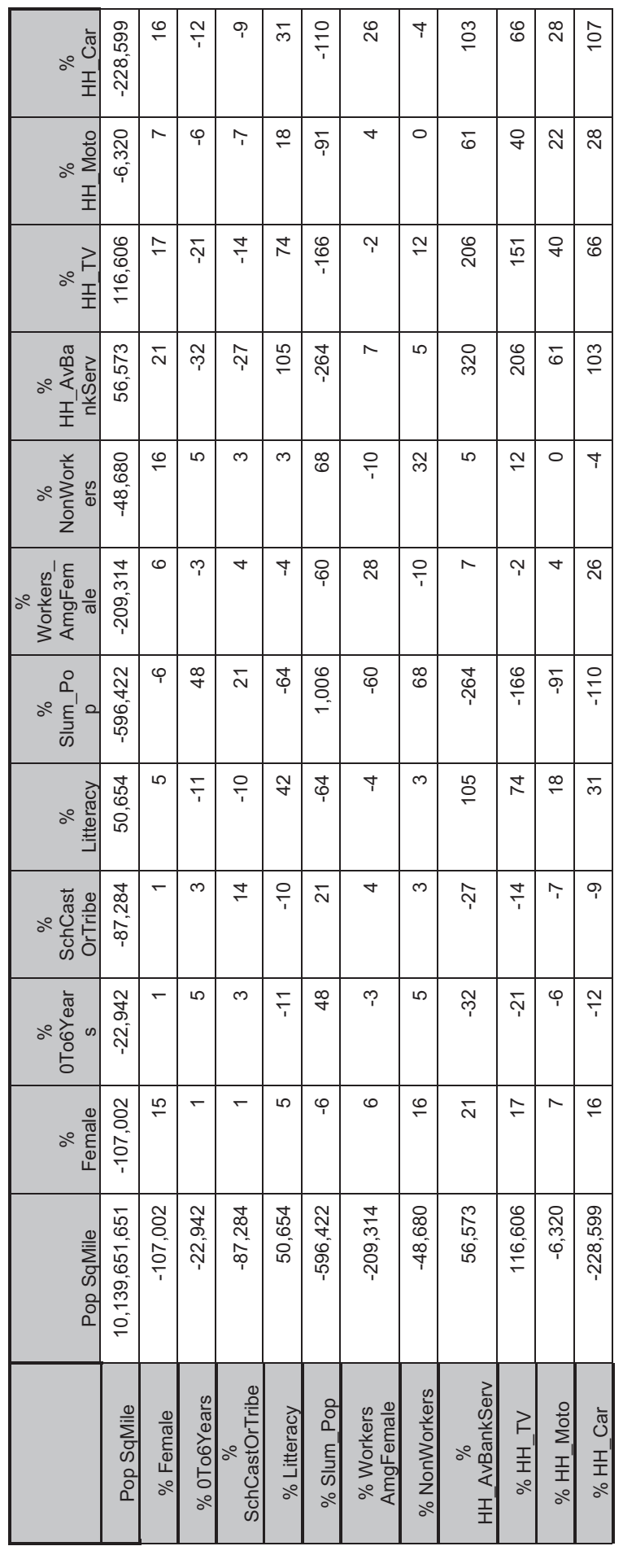


